Original paper

\title{
New constraints on the Polish moldavite finds: a separate sub-strewn field of the central European tektite field or re-deposited materials?
}

\author{
Roman SKÁLA ${ }^{1,2 *}$, Šárka JONÁŠOVÁ ${ }^{1,2}$, Karel ŽÁK' ${ }^{1}$ Jana ĎURIŠOVÁ ${ }^{1}$, Tomasz BRACHANIEC ${ }^{3}$, \\ Tomáš MAGNA ${ }^{4}$
}

${ }^{1}$ Institute of Geology, The Czech Academy of Sciences, Rozvojová 269, 16500 Prague 6, Czech Republic; skala@gli.cas.cz

${ }^{2}$ Institute of Geochemistry, Mineralogy and Mineral Resources, Faculty of Science, Charles University in Prague, Albertov 6, 12843 Prague 2, Czech Republic

${ }^{3}$ Department of Geochemistry, Mineralogy and Petrology, Faculty of Earth Sciences, University of Silesia, Bedzinska st. 60, 41-200 Sosnowiec, Poland

${ }^{4}$ Czech Geological Survey, Klárov 3, 11821 Prague 1, Czech Republic

* Corresponding author

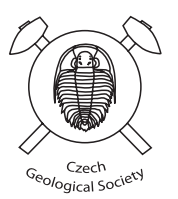

Moldavites are known to occur in several geographically limited areas in Central Europe: South Bohemia, Western Bohemia (Cheb Basin), Western Moravia, the Horn area in Upper Austria, and Lusatia in Germany. In addition to these traditional finds, Central European tektites (CET) have recently been identified in Neogene sediments at three places in Lower Silesia in Poland. Sandpits near Rusko and Mielęcin represent the most remote localities from the Ries impact structure with the distance of about $475 \mathrm{~km}$. The previously published data were limited to electron-microprobe analyses of four specimens. Here we provide additional compositional data for a single moldavite from the North Stanisław sandpit near Rusko. Combined data of electron microprobe (EPMA; major elements) and laser-ablation inductively-coupled-plasma mass spectrometry (LA-ICP-MS; minor and trace elements) provide new insights into chemical variability of CET. Electron-microprobe analyses supplemented with back-scattered electron images showed marked chemical heterogeneity of the Polish moldavite on the micrometre scale, confirmed also by LA-ICP-MS. The major-element composition of the volumetrically dominating glass of the specimen is indistinguishable from the majority of $c .5000$ available EPMA analyses of moldavites from other regions and, consequently, it does not provide any unambiguous link to any of these sub-strewn fields. Rare schlieren in the sample with unique $\mathrm{Ca}-\mathrm{Mg}$-rich composition have counterparts among several South Bohemian moldavites. In general, Polish moldavites are small (less than $0.5 \mathrm{~g}$ ) irregular fragments or splinters of angular shape with multistage sculpturing. Their morphological character and paleogeography of Central Europe in the last 15 Myr suggest that they were redeposited at time of the Gozdnica Fm. sedimentation from yet unknown sub-strewn field north of the Sudetic Mountains.

Keywords: moldavites, tektites, Lower Silesia, Poland, Ries impact structure, geochemistry

Received: 4 December, 2015; accepted: 3 May, 2016; handling editor: E. Jelínek

The online version of this article (doi: 10.3190/jgeosci.214) contains supplementary electronic material.

\section{Introduction}

Tektites are natural silica-rich glasses representing distal ejecta from parent impact structures. They occur in geographically limited areas, so-called strewn fields. Traditionally, four major strewn fields have been recognized: North American, Ivory Coast, Australasian, and central European, the latter being the smallest (Koeberl 2014 and references therein). Recently, the fifth strewn field has perhaps been recognized: Central American in Belize, possibly contemporaneous with the Australasian field (Povenmire et al. 2012; Schwarz et al. 2016). In addition to these findings, several small and isolated occurrences of tektites are known (e.g., urengoites: Ostermann et al. 1996; Deutsch et al. 1997; Argentinian tektites: Bland et al. 2002; Schultz et al. 2006).
Central European tektites (CET) are called moldavites. They were formed from the uppermost sedimentary rocks layer during the Ries-Steinheim impact event in Miocene. The recent occurrences of CET in several small areas (sub-strewn fields) reflect the paleogeography at the time of impact as well as further geological history of the area. These regions (Fig. 1) include south Bohemia and western Moravia (e.g., Bouška 1972; Bouška and Konta 1986; Trnka and Houzar 1991), Austria (Koeberl et al. 1988), Lusatia (Lange 1995, 1996), and the Cheb Basin (Bouška et al. 1995; Řanda et al. 2008; Skála et al. 2009). Beside these larger accumulations, other scattered finds were also reported, e.g., at Kobylisy sandpit in Prague (Žebera 1972), at a sandpit near Jeviněves north of Kralupy nad Vltavou (Žák et al. 1999), and on the Berounka river ter- 


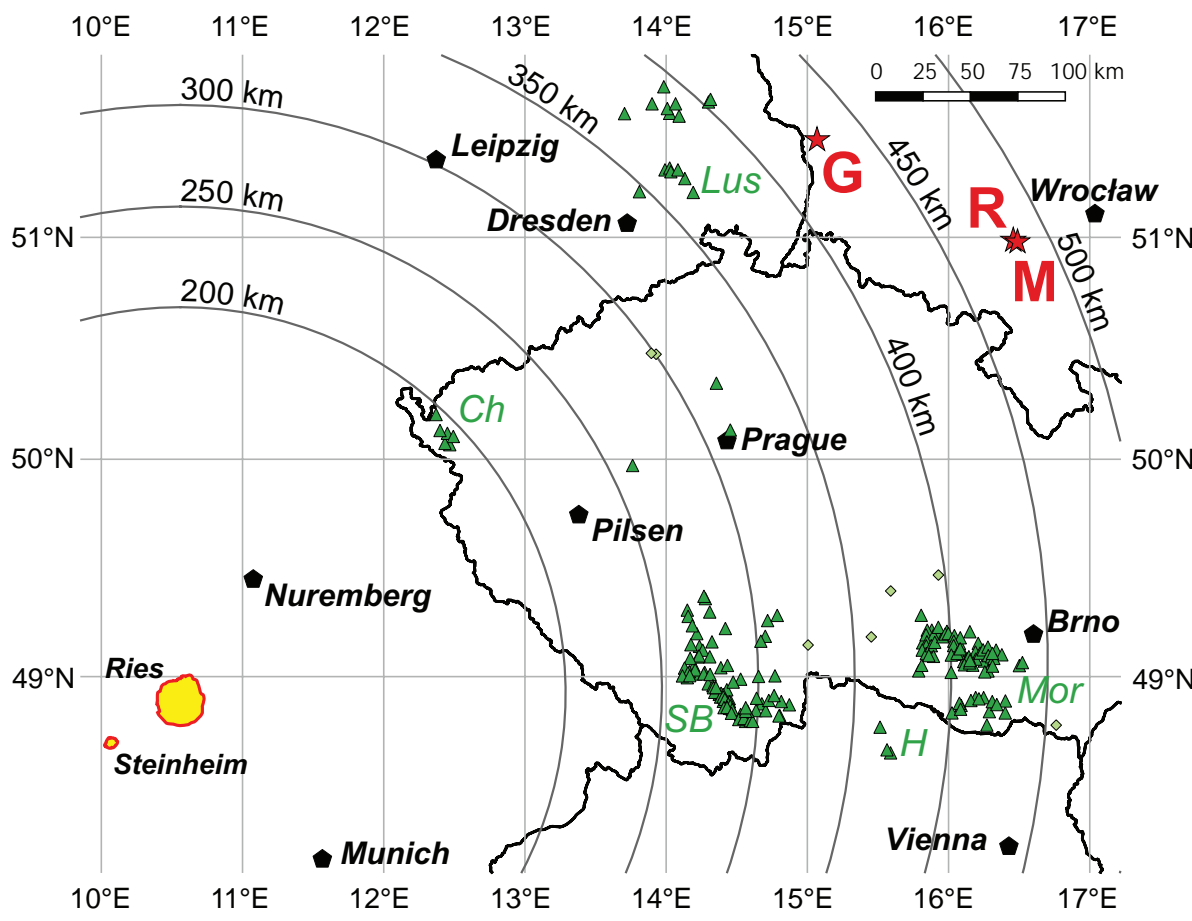

Fig. 1 Map of Central Europe illustrating the distribution of major moldavite localities. Red stars indicate Polish localities with moldavite finds: $\mathrm{R}=$ North Stanisław near Rusko, $\mathrm{M}=$ Mielęcin and $\mathrm{G}=$ Gozdnica. Green triangles show locations of selected moldavite occurrences across CET strewn field whereas light green diamonds stand for uncertain or unconfirmed finds. The Ries and Steinheim impact structures are also shown. Sub-strewn fields: $\mathrm{Ch}=$ Cheb, $\mathrm{H}=$ Horn, Lus = Lusatia, Mor = Moravia, SB = South Bohemia. race near Skryje (Ložek and Žák 2011). A detailed review of moldavite occurrences and chemical properties was given by Trnka and Houzar (2002).

The parent impact structure of moldavites is the Ries crater in Bavaria, Germany. Source materials of CET were identified as mineralogically and chemically variable sediments of the Upper Freshwater Molasse (Obere Süßwasser Molasse) (von Engelhardt et al. 1987, 2005; Skála et al. 2009 and references therein). Recently, a possible role of organic matter has been discussed by Řanda et al. (2008) and Žák et al. (2012). Žák et al. (2016) reviewed the available compositional data for CET and Obere Süßwasser Molasse sediments, and in this framework discussed the possible genesis of moldavites. Best estimates of the moldavite age as well as that of the Ries structure corrected for most recently suggested ${ }^{40} \mathrm{~K}$ decay constants (Jourdan et al. 2012) currently vary between $14.74 \pm 0.20 \mathrm{Ma}(2 \sigma)$ and 14.83 $\pm 0.15 \mathrm{Ma}$ (Di Vincenzo and Skála 2009; Buchner et al. 2010, 2013; Schwarz and Lippolt 2014).

Until recently, the largest recorded distance of any moldavite occurrence from the center of the Ries structure did not exceed $\sim 420 \mathrm{~km}$. Brachaniec et al. (2014) found nine fragments of moldavites in the North Stanisław sandpit $\left(50.9948^{\circ} \mathrm{N}, 16.9629^{\circ} \mathrm{E}\right)$ close to village Rusko near Strzegom, southwest of Wrocław, Poland, at a distance of about $475 \mathrm{~km}$ from the Ries crater center (Fig. 1). They reported nine electron microprobe analyses for one of the moldavites, limited to the determination of the major elements. Recently, Brachaniec et al. (2015) confirmed the occurrence of moldavites in Poland by further finds in sandpits in Gozdnica $\left(51.4405^{\circ} \mathrm{N}, 15.0668^{\circ} \mathrm{E}\right.$; six pieces), Mielęcin $\left(50.9724^{\circ} \mathrm{N}, 16.4975^{\circ} \mathrm{E}\right.$; two pieces) and again
North Stanisław sandpit (one piece) and provided 30 new microprobe analyses of major elements for one moldavite from each of the three Polish localities. Based on these compositional data and size of individual finds they concluded that Polish moldavites were re-deposited from the Lusatian sub-strewn field by fluvial transport in Late Miocene.

The recent find of moldavites in Poland significantly extends the entire CET strewn field yet chemical data are limited and associated with analytical artefacts. Therefore, we provide additional major-element data, supplemented by first minor- and trace-element compositions. The newly collected data allow comparison with existing datasets from other sub-strewn fields. This approach allows assessing the origin of moldavites in Poland, i.e. testing whether they represent tektites transported from the Lusatian sub-strewn field (Brachaniec et al. 2014, 2015) or if they form a new separate sub-strewn field.

\section{Experimental}

The material available for the present study is the part of the sample NS-4 of Brachaniec et al. (2014). Macroscopic appearance of its surface was documented with a binocular lens Olympus SZX-16 coupled to an Olympus SP-350 digital camera. The surface of the moldavite specimen was also imaged using a variable pressure scanning electron microscope (SEM) TESCAN VEGA 3XM, housed at the Institute of Geology of the Czech Academy of Sciences in Prague (IG CAS) without coating to prevent possible contamination due to coating/sputtering. 
The microscope was operated at an accelerating voltage of $20 \mathrm{kV}$, the current was set to obtain optimum image resolution and a back-scattered electron (BSE) detector was used to collect the images.

After characterization of the surface, the sample was mounted to a standard microprobe 1-inch epoxy holder, sectioned and polished. The polished surface was imaged by a binocular lens, followed by BSE imaging to reveal the inner structure. The accelerating voltage applied was $20 \mathrm{kV}$ and the current was optimized to yield the best image resolution. To illustrate further details which remain unobserved in BSE images we also performed cathodoluminescence (CL) imaging using TESCAN colour CL detector attached to the SEM.

Major-element data were collected with the CAMECA SX-100 electron probe microanalyzer (EPMA) hosted at the IG CAS. An accelerating voltage was $15 \mathrm{kV}$ and the sample current $4 \mathrm{nA}$. Beam was defocused to the diameter of $5 \mu \mathrm{m}$ in order to reduce volatile loss during analysis. Analyzed elements included Si (sanidine standard, $970 \mathrm{ppm}$ typical detection limit), Ti (rutile, $390 \mathrm{ppm}$ ), Al (jadeite, 670 ppm), Fe (magnetite, 1000 ppm), Mn (rhodonite, $750 \mathrm{ppm}$ ), $\mathrm{Mg}$ (periclase, $570 \mathrm{ppm}$ ), Ca (diopside, $460 \mathrm{ppm}$ ), $\mathrm{Na}$ (jadeite, $950 \mathrm{ppm}$ ), and $\mathrm{K}$ (sanidine, 470 $\mathrm{ppm}$ ). The concentrations of other elements were below detection limits. All elements were quantified using the $K_{\alpha}$ lines. Counting time on peak was $40 \mathrm{~s}$ for $\mathrm{Fe}$ and $\mathrm{Mn}$, and $10 \mathrm{~s}$ for other elements. The background level was measured on both sides of each peak and the acquisition time was half of that on the peak. Secondary standards albite, diopside, obsidian and kaersutite (Structure Probe, Inc., USA) were used to assess the analytical precision.

Trace-element concentrations were determined on a polished thick section using a high-resolution Thermo Finnigan Element 2 ICP-MS coupled to a $213 \mathrm{~nm}$ Nd:YAG laser-ablation system UP-213 (New Wave Research) housed at the IG CAS. In homogenous areas, spot analyses of $80 \mu \mathrm{m}$ diameter were carried out. Elsewhere, a line profile ( $55 \mu \mathrm{m}$ beam diameter, $1000 \mu \mathrm{m}$ length) was measured across the schlieren, with the speed of $1 \mu \mathrm{m} / \mathrm{s}$. In lechatelierite inclusions, the laser diameter was adapted to the size of the inclusion, i.e. $40 \mu \mathrm{m}$ or $55 \mu \mathrm{m}$. In all cases, the laser repetition rate was $20 \mathrm{~Hz}$, and the fluence $9-10 \mathrm{~J} / \mathrm{cm}^{2}$.

The following isotopes were measured in the low-mass resolution mode (LR): ${ }^{7} \mathrm{Li},{ }^{9} \mathrm{Be},{ }^{11} \mathrm{~B},{ }^{31} \mathrm{P},{ }^{45} \mathrm{Sc},{ }^{47} \mathrm{Ti},{ }^{51} \mathrm{~V},{ }^{53} \mathrm{Cr}$, ${ }^{55} \mathrm{Mn},{ }^{59} \mathrm{Co},{ }^{61} \mathrm{Ni},{ }^{65} \mathrm{Cu},{ }^{66} \mathrm{Zn},{ }^{74} \mathrm{Ge},{ }^{75} \mathrm{As},{ }^{85} \mathrm{Rb},{ }^{88} \mathrm{Sr},{ }^{89} \mathrm{Y},{ }^{91} \mathrm{Zr}$, ${ }^{93} \mathrm{Nb},{ }^{95} \mathrm{Mo},{ }^{107} \mathrm{Ag},{ }^{111} \mathrm{Cd},{ }^{118} \mathrm{Sn},{ }^{121} \mathrm{Sb},{ }^{133} \mathrm{Cs},{ }^{137} \mathrm{Ba},{ }^{139} \mathrm{La}$, ${ }^{140} \mathrm{Ce},{ }^{141} \mathrm{Pr},{ }^{146} \mathrm{Nd},{ }^{147} \mathrm{Sm},{ }^{151} \mathrm{Eu},{ }^{157} \mathrm{Gd},{ }^{159} \mathrm{~Tb},{ }^{165} \mathrm{Ho},{ }^{166} \mathrm{Er}$, ${ }^{169} \mathrm{Tm},{ }^{172} \mathrm{Yb},{ }^{175} \mathrm{Lu},{ }^{178} \mathrm{Hf},{ }^{181} \mathrm{Ta},{ }^{182} \mathrm{~W},{ }^{197} \mathrm{Au},{ }^{208} \mathrm{~Pb},{ }^{209} \mathrm{Bi}$, ${ }^{232} \mathrm{Th}$, and ${ }^{238} \mathrm{U}$. In the homogeneous part, the following isotopes were acquired in medium-mass resolution mode (MR): ${ }^{31} \mathrm{P},{ }^{45} \mathrm{Cc},{ }^{47} \mathrm{Ti},{ }^{51} \mathrm{~V},{ }^{52} \mathrm{Cr},{ }^{55} \mathrm{Mn},{ }^{59} \mathrm{Co},{ }^{60} \mathrm{Ni},{ }^{63} \mathrm{Cu},{ }^{66} \mathrm{Zn}$, and ${ }^{69} \mathrm{Ga}$ in order to eliminate polyatomic spectral interferences. In lechatelierite inclusions, the isotopes measured in MR included: ${ }^{23} \mathrm{Na},{ }^{24} \mathrm{Mg},{ }^{27} \mathrm{Al},{ }^{31} \mathrm{P},{ }^{39} \mathrm{~K},{ }^{44} \mathrm{Ca},{ }^{45} \mathrm{Sc},{ }^{47} \mathrm{Ti}$, ${ }^{51} \mathrm{~V},{ }^{52} \mathrm{Cr},{ }^{55} \mathrm{Mn},{ }^{56} \mathrm{Fe},{ }^{59} \mathrm{Co},{ }^{60} \mathrm{Ni},{ }^{63} \mathrm{Cu},{ }^{66} \mathrm{Zn}$, and ${ }^{69} \mathrm{Ga}$.

The analyzed isotopes were acquired in time-resolved mode, which does not allow simultaneous acquisition of LR and MR. Thus two spots or two line rasters next to each other were ablated in order to obtain the complete element set in each case. External calibration was done using NIST SRM 612 glass (Jochum et al. 2011). Internal normalization to ${ }^{29} \mathrm{Si}$ concentration based on EPMA measurement was applied. The time-resolved analyses were processed using the Iolite software (Paton et al. 2011).

\section{Results}

\subsection{Appearance}

Dimensions of the studied brown-green fragment of moldavite were $5 \times 3 \times 4 \mathrm{~mm}$ and its weight was $125 \mathrm{mg}$. The surface was decorated with a marked sculpturing. Under
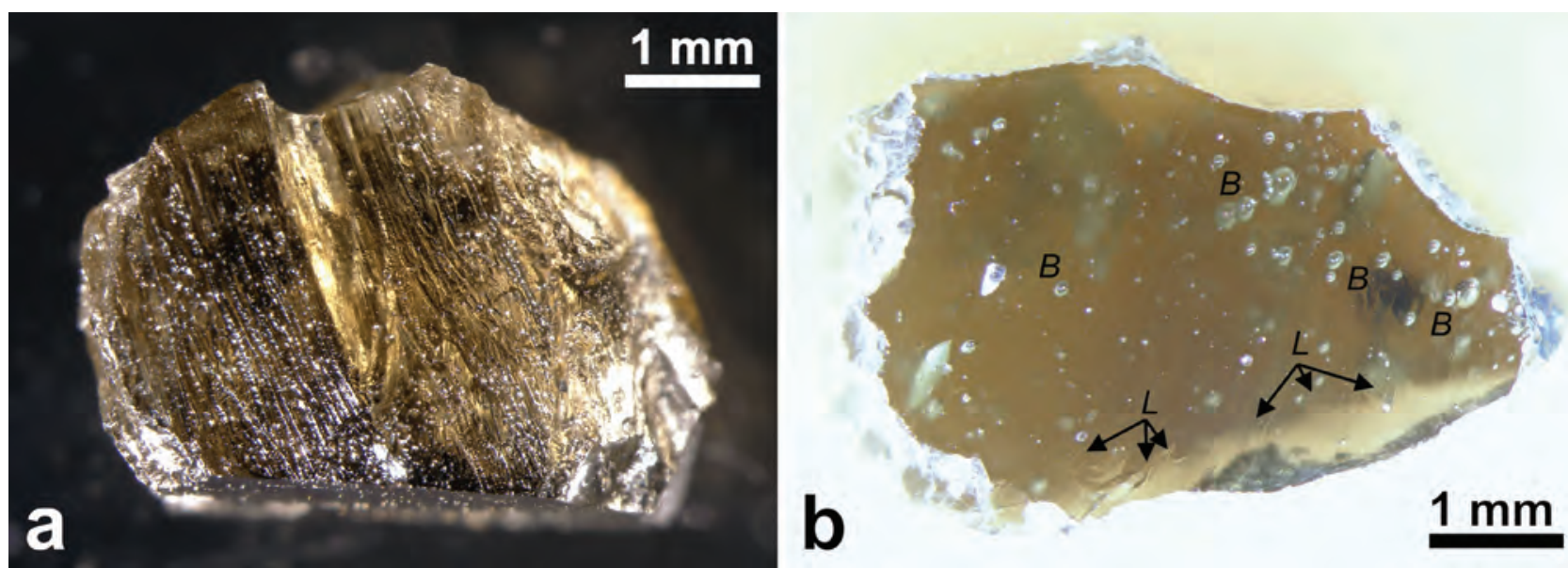

Fig. 2 Sculpturing on the surface of studied Polish moldavite under binocular lens in combined transmitted and reflected light (a). On the polished section in reflected light, numerous bubbles (B) and lechatelierite inclusions (L) appear (b). 

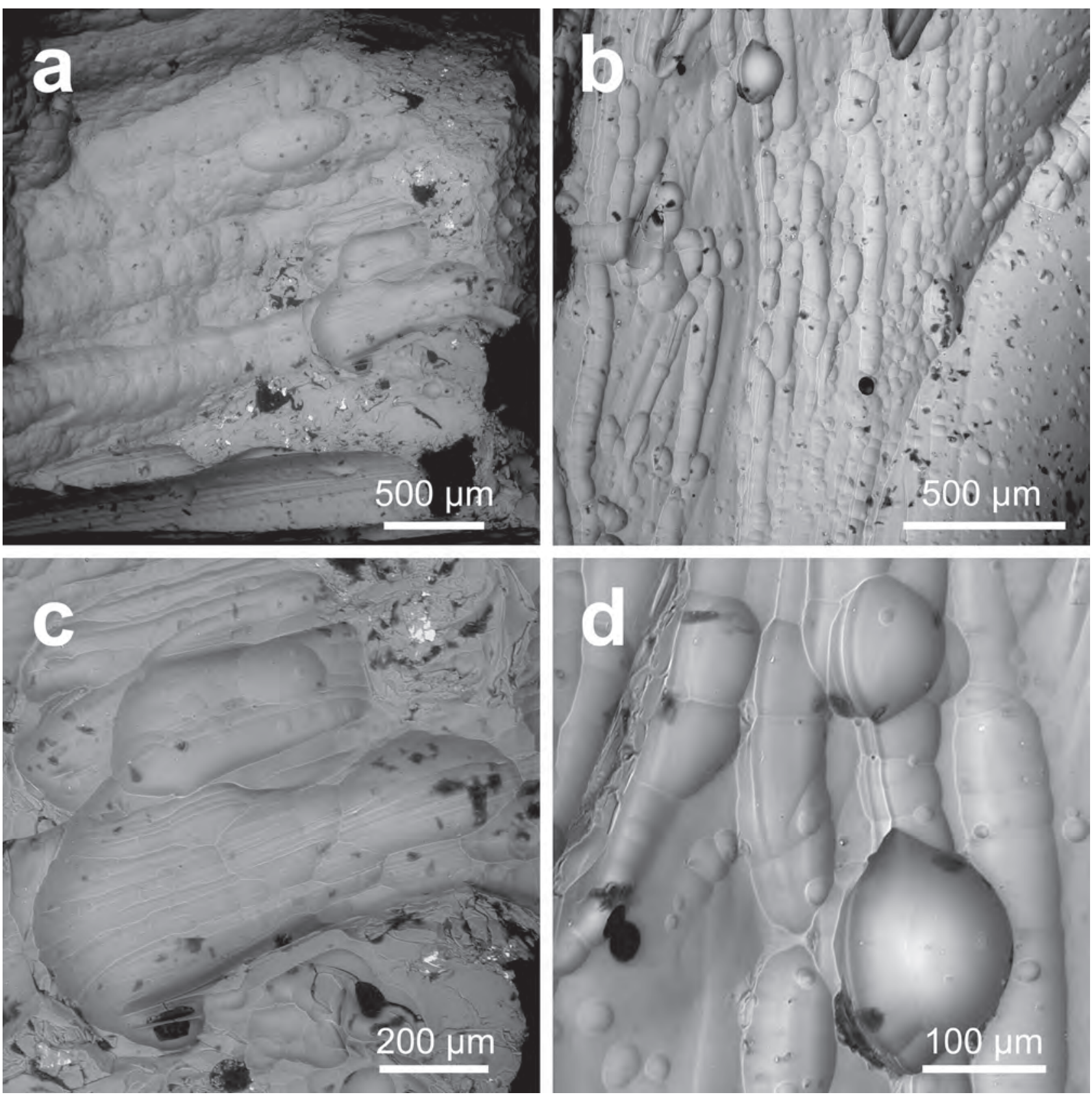

Fig. 3 Images of the surface of the moldavite from the North Stanisław sandpit taken by SEM under low vacuum employing BSE detector. Surface is shaped by sub-parallel grooves tens $\mu \mathrm{m}$ to almost half a millimetre wide highlighting a fluidal fabric of the moldavite visible under binocular lens (a); pit sculpturing further reshapes these grooves (b); some larger pits are possibly relics of former bubbles and may show fine striation on their walls highlighting the overall fluidal fabric (c); youngest sculpturing is formed by small circular flat depressions mostly less than $5 \mu \mathrm{m}$ in diameter (d).

the binocular lens, the moldavite displayed pronounced fluidal structure on its surface (Fig. 2a). After sectioning, numerous bubbles and lechatelierite inclusions appeared (Fig. 2b). The bubbles are mostly spherical and only sporadically elongated. Their sizes are variable but most are less than $100 \mu \mathrm{m}$ across. Lechatelierite inclusions display different shapes and sizes; thin and long fibres and ribbons are often distorted.
The surface of the moldavite imaged with SEM exhibited a presence of more or less parallel furrows of variable widths ranging from tens of $\mu \mathrm{m}$ to almost half a millimetre (Fig. 3a). These furrows often are further reshaped by pit sculpturing (Fig. 3b). Some larger pits represent opened bubbles. Figure $3 \mathrm{~b}$ illustrates a flat surface with scattered circular pits only few $\mu \mathrm{m}$ across. In elliptical pits superimposed on furrows, fine striae may be noticed highlighting the overall fluidal fabric 

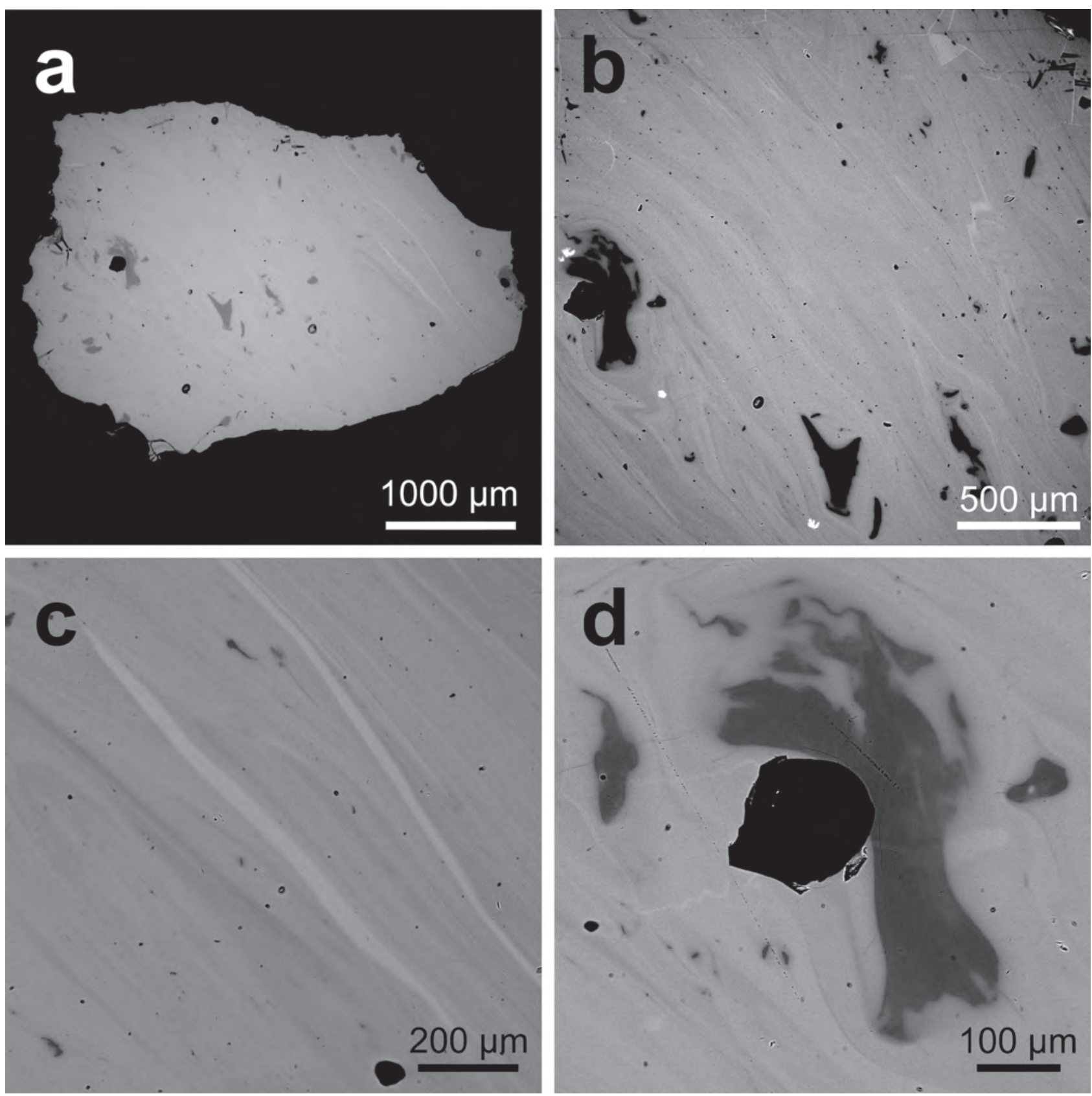

Fig. 4 Back-scattered electron images of the sample NS-4 show entire area of the studied polished section illustrating the distribution of lechatelierite inclusions and the overall fluidal fabric (a); more detailed view of lechatelierite grains [dark grey coloured] up to $400 \mu \mathrm{m}$ across engulfed among intermingled thin compositionally different schlieren, and bubbles of different sizes [black] (b); presence of bright high-Ca-Mg lamellae (c) and influence of the bubble [black] on the shape of the lechatelierite inclusion and orientation of schlieren (d).

of the studied sample (Fig. 3c). Figure 3d shows small circular yet flat depressions usually not larger than $5 \mu \mathrm{m}$ in diameter further decorating other types of sculpturing.

Our moldavite specimen is chemically heterogeneous as demonstrated by BSE images. Figure 4a shows distribution of lechatelierite inclusions and illustrates the overall fluidal fabric of this moldavite. The details of the fluidal fabric consisting of mutually alternating and interwoven fine chemically different schlieren are illustrated in Figs $4 b-d$. Figure $4 d$ also shows a complex shape of a lechatelierite inclusion and interaction of fluidal fabric with that inclusion and a bubble. Figure 5 presents BSE and CL images of lechatelierite inclusions; the CL image displays a brighter rim within lechatelierite located along the inclusion boundary which is separated from the moldavite glass with a thin dark line. 


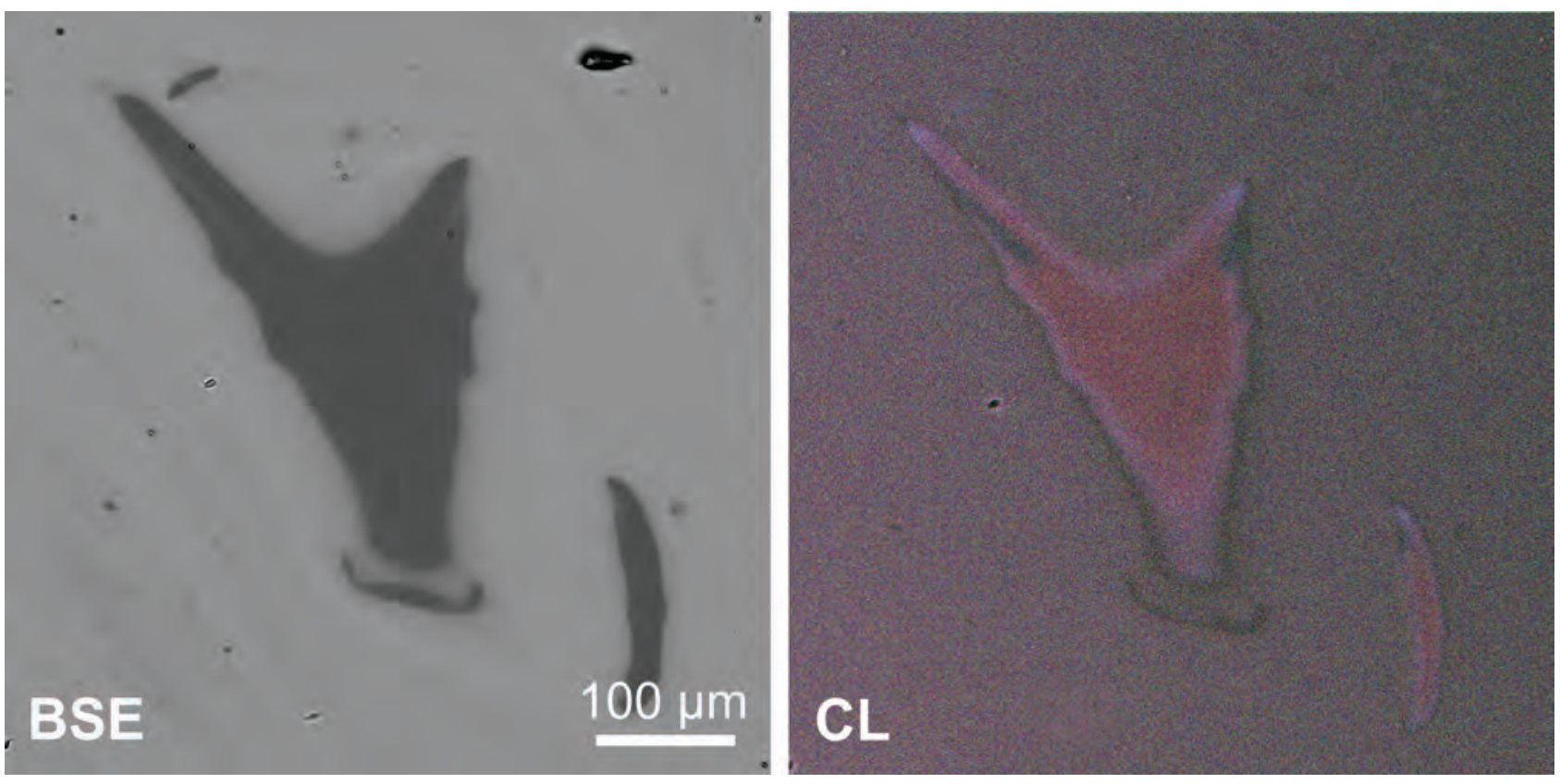

Fig. 5 Back-scattered electron and CL images of lechatelierite inclusions demonstrating their heterogeneity. Note different colouring of CL image along grain boundaries which is not observed in the BSE image.

\subsection{Chemical composition}

The BSE images illustrate that the sample NS-4 is chemically highly variable on a micrometre scale. The electron-microprobe analyses reflect this variability, evidenced by large variations in major-element concentrations (Tab. 1). Two prominent schlieren (Figs 4a, c) differ substantially from the other analyses. In much of the specimen, $\mathrm{SiO}_{2}$ contents vary between 76 and 82 wt. \%, whereas the glass of the schlieren contains only $\sim 74$ wt. $\% \mathrm{SiO}_{2}$. Other elements displaying considerable differences include $\mathrm{MgO}$ (average content of $1.4 \mathrm{wt}$. $\%$ in more siliceous glass vs. 4.0 wt. $\%$ in schlieren), $\mathrm{CaO}(1.7$ vs. 5.5 wt. $\%)$ and $\mathrm{K}_{2} \mathrm{O}(4.0$ vs. 2.9 wt. \%). It

Tab. 1 Major-element compositions (in wt. \%) of the NS-4 moldavite from Poland

\begin{tabular}{|c|c|c|c|c|c|c|}
\hline \multirow[b]{3}{*}{$\mathrm{n}$} & \multicolumn{3}{|c|}{ Low-Ca-Mg glass } & \multicolumn{3}{|c|}{ High-Ca-Mg glass } \\
\hline & Range & Mean & $\mathrm{SD}$ & Range & Mean & SD \\
\hline & \multicolumn{3}{|c|}{88} & \multicolumn{3}{|c|}{9} \\
\hline $\mathrm{SiO}_{2}$ & $76.12-82.15$ & 78.16 & 1.09 & $73.49-74.92$ & 74.16 & 0.49 \\
\hline $\mathrm{TiO}_{2}$ & $0.28-0.46$ & 0.37 & 0.04 & $0.21-0.30$ & 0.26 & 0.03 \\
\hline $\mathrm{Al}_{2} \mathrm{O}_{3}$ & $9.52-11.88$ & 11.10 & 0.45 & $9.83-10.60$ & 10.18 & 0.25 \\
\hline $\mathrm{FeO}_{\text {tot }}$ & $1.38-2.68$ & 2.27 & 0.27 & $1.89-2.24$ & 2.06 & 0.12 \\
\hline $\mathrm{MnO}$ & $0.00-0.12$ & 0.05 & 0.03 & $0.16-0.28$ & 0.21 & 0.04 \\
\hline $\mathrm{MgO}$ & $0.68-2.01$ & 1.44 & 0.22 & $3.79-4.19$ & 4.00 & 0.13 \\
\hline $\mathrm{CaO}$ & $0.73-2.97$ & 1.67 & 0.36 & $5.16-5.64$ & 5.45 & 0.15 \\
\hline $\mathrm{Na}_{2} \mathrm{O}$ & $0.40-0.84$ & 0.65 & 0.09 & $0.36-0.61$ & 0.46 & 0.08 \\
\hline $\mathrm{K}_{2} \mathrm{O}$ & $3.70-4.40$ & 4.02 & 0.12 & $2.81-3.13$ & 2.94 & 0.10 \\
\hline Total & $98.59-101.23$ & 99.73 & 0.55 & $98.97-100.41$ & 99.70 & 0.47 \\
\hline
\end{tabular}

The ranges, means, standard deviations (SD) and number of spot analyses involved in the calculation (n) are shown separately for high-Si and low-Ca-Mg glass and low-Si high-Ca-Mg schlieren. should be noted, however, that even the predominant, more $\mathrm{Si}$-rich low-Ca- $\mathrm{Mg}$ glass is rather heterogeneous (see Fig. 4c) resulting in large chemical variability; relative standard deviations of averaged data exceed $10 \%$ for $\mathrm{Ca}, \mathrm{Mg}, \mathrm{Na}, \mathrm{Fe}$, and $\mathrm{Ti}$ ( $\mathrm{Mn}$ is not considered due to low overall content). The compositional variability is illustrated in Figs 6-9 where the new data are compared to the published ones (Koeberl et al. 1988; Lange 1995; Skála et al. 2009) as well as authors' unpublished EPMA analyses for moldavites from other sub-strewn fields. Moreover, these plots demonstrate a strongly bimodal distribution attesting to the presence of two high- $\mathrm{Ca}-\mathrm{Mg}$ schlieren noted above. Figure 6 shows general negative correlations between most major-element oxides (except alkali elements) and silica, a feature which was described previously (e.g., O'Keefe 1976; Koeberl 1990). The glass of the sample NS-4 shows, in accord to other CET, positive correlations of $\mathrm{Al}_{2} \mathrm{O}_{3}$ with $\mathrm{TiO}_{2}$, $\mathrm{FeO}, \mathrm{Na}_{2} \mathrm{O}$, and $\mathrm{K}_{2} \mathrm{O}$ (Fig. 7); a correlation involving $\mathrm{Na}_{2} \mathrm{O}$ is likely due to alkali feldspars in source sediments whereas $\mathrm{K}$ may come from both feldspars and mafic minerals that also carried $\mathrm{Ti}$ and $\mathrm{Fe}$. Figure 8 shows strong positive correlations between $\mathrm{MgO}$ and $\mathrm{CaO}$, which have been reported 


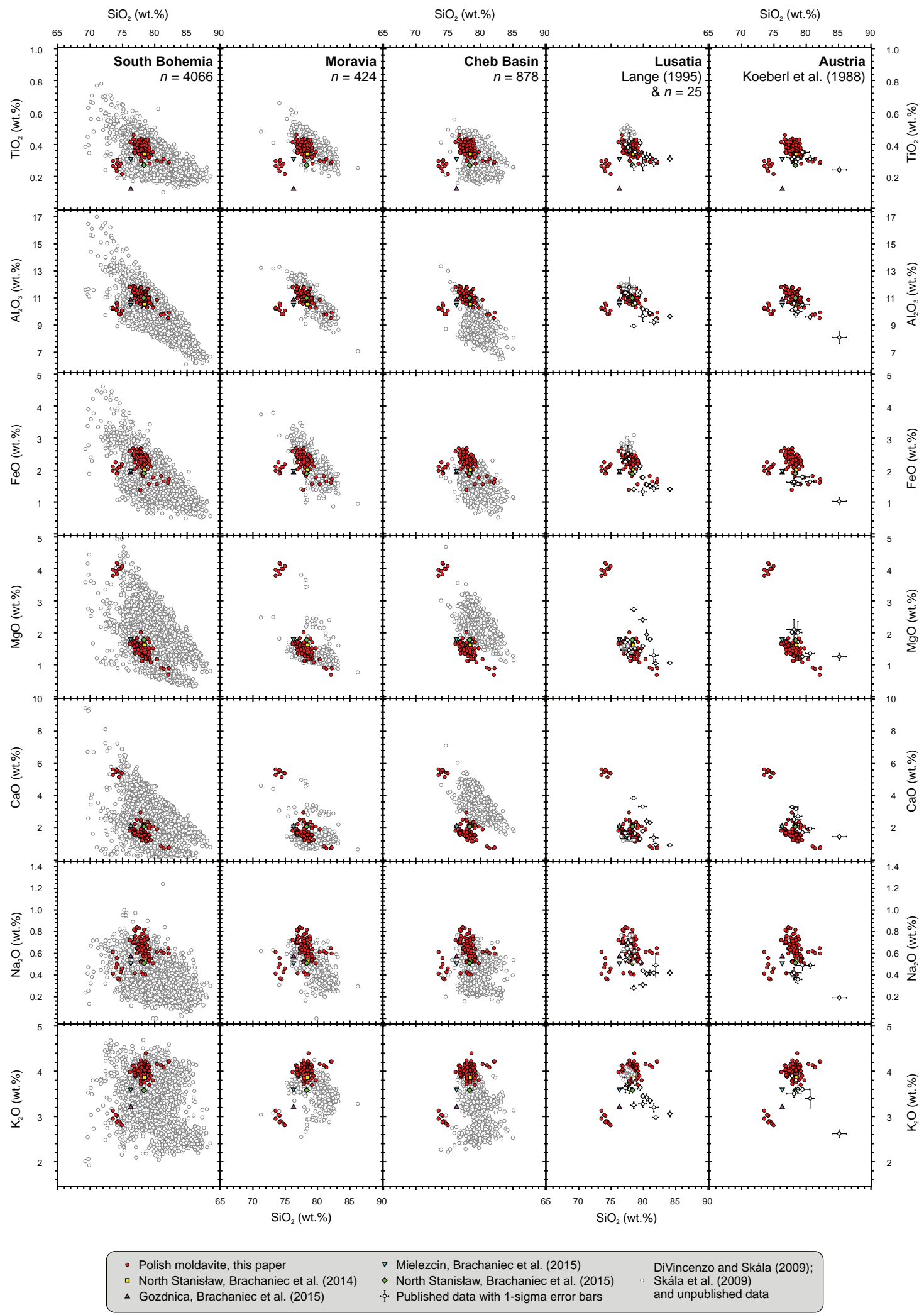

Fig. 6 Harker diagrams for the NS-4 moldavite. Shown for comparison are data presented for other Polish moldavites by Brachaniec et al. (2014, 2015), Lusatian moldavites by Lange (1995), and Austrian moldavites by Koeberl et al. (1988). Data for South Bohemian, Moravian, Cheb and partly Lusatian moldavites either come from Skála et al. (2009) and Di Vincenzo and Skála (2009) or they represent unpublished authors' analyses. Also note that analyses of Polish moldavites from Gozdnica (purple triangle) and North Stanisław (green diamond) sandpits from Brachaniec et al. (2015) display low analytical totals indicating some analytical artefacts. Consequently, their actual position in plots may be slightly different. 


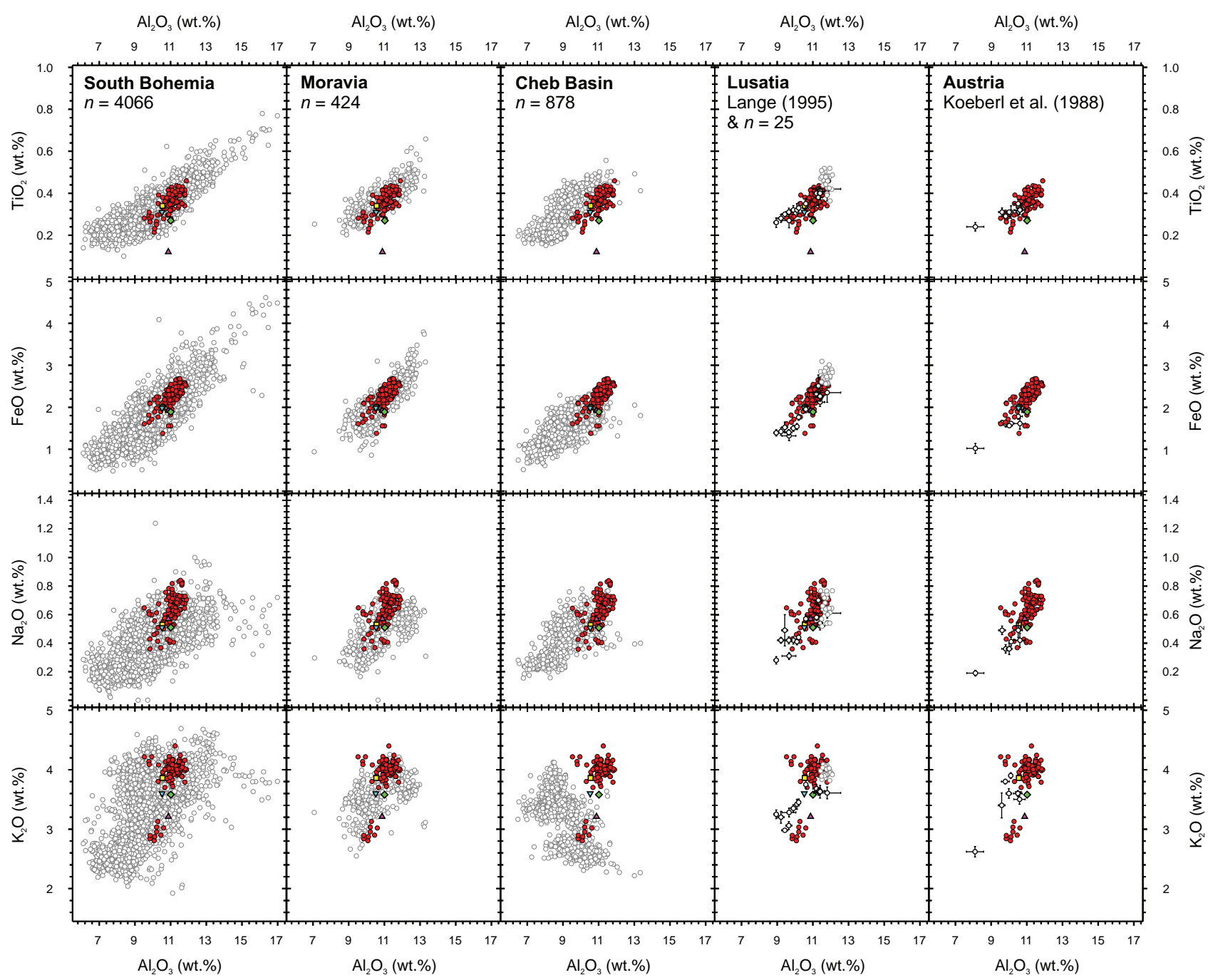

Fig. 7 Variation of $\mathrm{TiO}_{2}, \mathrm{FeO}_{\text {tot }}, \mathrm{Na}_{2} \mathrm{O}$ and $\mathrm{K}_{2} \mathrm{O}$ versus $\mathrm{Al}_{2} \mathrm{O}_{3}$ contents (in wt. \%) for the sample NS-4 compared to EPMA data for moldavites from the classical sub-strewn fields. Symbols and data sources as in Fig. 6.

earlier (e.g., Bouška and Konta 1986; Koeberl 1990; Trnka and Houzar 2002; Skála et al. 2009), and variable trends for $\mathrm{CaO}$ vs. $\mathrm{K}_{2} \mathrm{O}$, which was demonstrated to be unique for the moldavites from the Cheb Basin (Skála et al. 2009). These diagrams also underscore the unusual composition of the high-Ca-Mg schlieren, which is scarce among the $c .5000$ available EPMA analyses of moldavites; several comparable data occur only among South Bohemian moldavites. No analysis of the sample NS-4, however, corresponds to the so-called $\mathrm{HCa} / \mathrm{Mg}$-types $(\mathrm{CaO} / \mathrm{MgO} \sim 2.0)$ identified in the South Bohemian (Bouška and Konta 1986) or Cheb (Skála et al. 2009) sub-strewn fields. A broad linear trend between $\mathrm{Na}_{2} \mathrm{O}$ and $\mathrm{K}_{2} \mathrm{O}$ observed for South Bohemian, Moravian and Lusatian moldavites is not so obvious for the NS-4 moldavite (Fig. 9). Instead, the data for our sample are grouped into two separate offset clusters corresponding to the two glass types present in the specimen. A plot of $\mathrm{Na}_{2} \mathrm{O} / \mathrm{K}_{2} \mathrm{O}$ vs. $\mathrm{Na}_{2} \mathrm{O}$ (Fig. 9) also illustrates two separate trends with that of high-Ca-Mg schlieren displaying highly unusual composition among other analyzed CET.

Oxide ratio plots [i.e., $\mathrm{X} / \mathrm{MgO}\left(\mathrm{X}=\mathrm{SiO}_{2}, \mathrm{Al}_{2} \mathrm{O}_{3}, \mathrm{FeO}\right.$, $\mathrm{Na}_{2} \mathrm{O}$ and $\mathrm{K}_{2} \mathrm{O}$ ) vs. $\mathrm{CaO} / \mathrm{TiO}_{2}$ - Fig. 10] were traditionally used to distinguish moldavites found in different substrewn fields (e.g., Delano and Lindsley 1982). However, it was later demonstrated (e.g., Koeberl et al. 1988; Skála et al. 2009) that the utility of these diagrams is rather limited. Indeed, the high-Si low-Ca-Mg glass of the sample NS-4 mimics CET from the Moravian sub-strewn field whereas low-Si high-Ca-Mg glass of schlieren plots in the region characteristic mostly of moldavites from the Cheb Basin and partly also from the South Bohemian sub-strewn field.

Minor- and trace-element composition determined for the volumetrically dominant, rather homogeneous glass in the sample is given in Tab. 2. Further data were collected along a profile crossing a chemically more heterogeneous part shown in Fig. 4c. 


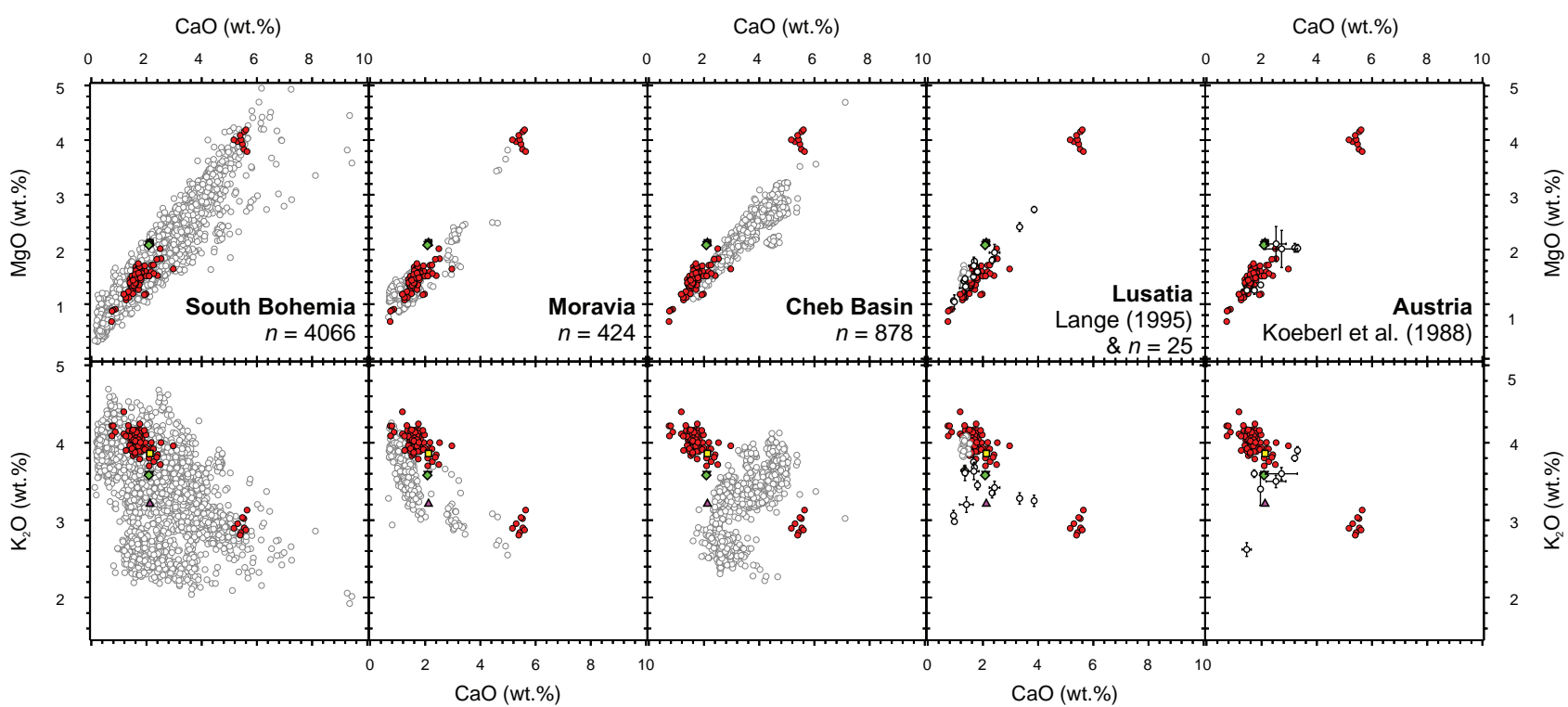

Fig. 8 Variation of $\mathrm{MgO}$ and $\mathrm{K}_{2} \mathrm{O}$ versus $\mathrm{CaO}$ contents (in wt. \%) in the NS-4 moldavite compared to EPMA data for moldavites from the traditional sub-strewn fields. Symbols and data sources as in Fig. 6.

Chondrite-normalized REE patterns of the specimen (Fig. 11) overlap with those of other sub-strewn fields though the complete match is found only for South Bohemian and Cheb Basin moldavites. The compositional field of the NS-4 moldavite partially plots below the CI-normalized REE ranges for Moravian, Lusatian and Austrian CET. The sample shows enrichment in LREE over HREE characterized by average $(\mathrm{La} / \mathrm{Yb})_{\mathrm{N}}$ and $(\mathrm{Ce} /$ $\mathrm{Yb})_{\mathrm{N}}$ values of 10.9 and 9.3, respectively; there is also a significant negative $\mathrm{Eu}$ anomaly $\left(\mathrm{Eu} / \mathrm{Eu}^{*}=0.56-0.80\right)$. The REE patterns are compatible with those for mature Phanerozoic sediments having $(\mathrm{La} / \mathrm{Yb})_{\mathrm{N}}$ of $10-14,(\mathrm{Ce} /$ $\mathrm{Yb})_{\mathrm{N}}$ of 7-11, and $\mathrm{Eu} / \mathrm{Eu}^{*}$ of c. $0.65-0.70$ (Condie 1993).
Some other incompatible trace-element parameters for the sample NS-4 are in general close to those for the upper continental crust (UCC values from Rudnick and Gao 2014), in particular Sm/Nd with an average value of 0.194 in the studied moldavite vs. 0.174 for UCC, Lu/ Hf 0.043 vs. $0.058, \mathrm{Th} / \mathrm{Sm} 2.40$ vs 2.23 or $\mathrm{La} / \mathrm{Nb} 3.03$ vs. 2.58. Average $\mathrm{Zr} / \mathrm{Hf}$ is 38.5 , consistent with data of David et al. (2000), who reported close to chondritic $\mathrm{Zr} / \mathrm{Hf}$ ratios $[\mathrm{Zr} / \mathrm{Hf}=34.3$ for chondrites (Münker et al. 2003)] for most continental crust materials. The $\mathrm{Nb} / \mathrm{Ta}$ ratios vary between 10.7 and 15.4; these values agree with those given for loess and shales by Barth et al. (2000) and Kamber et al. (2005). Contrary to this,

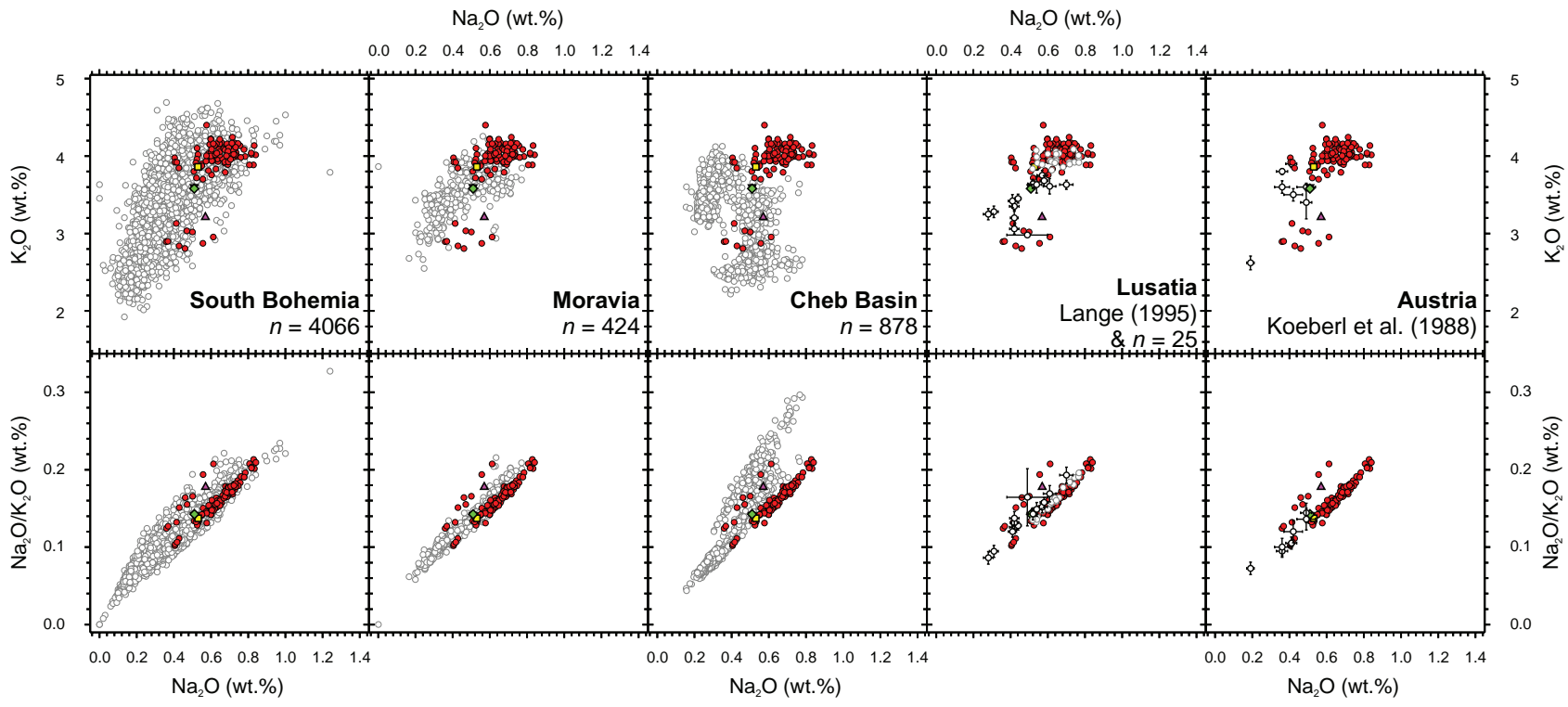

Fig. 9 Alkali element and alkali element ratio plot for the sample NS-4 compared to EPMA data for moldavites from the classical sub-strewn fields. Symbols and data sources as in Fig. 6. 


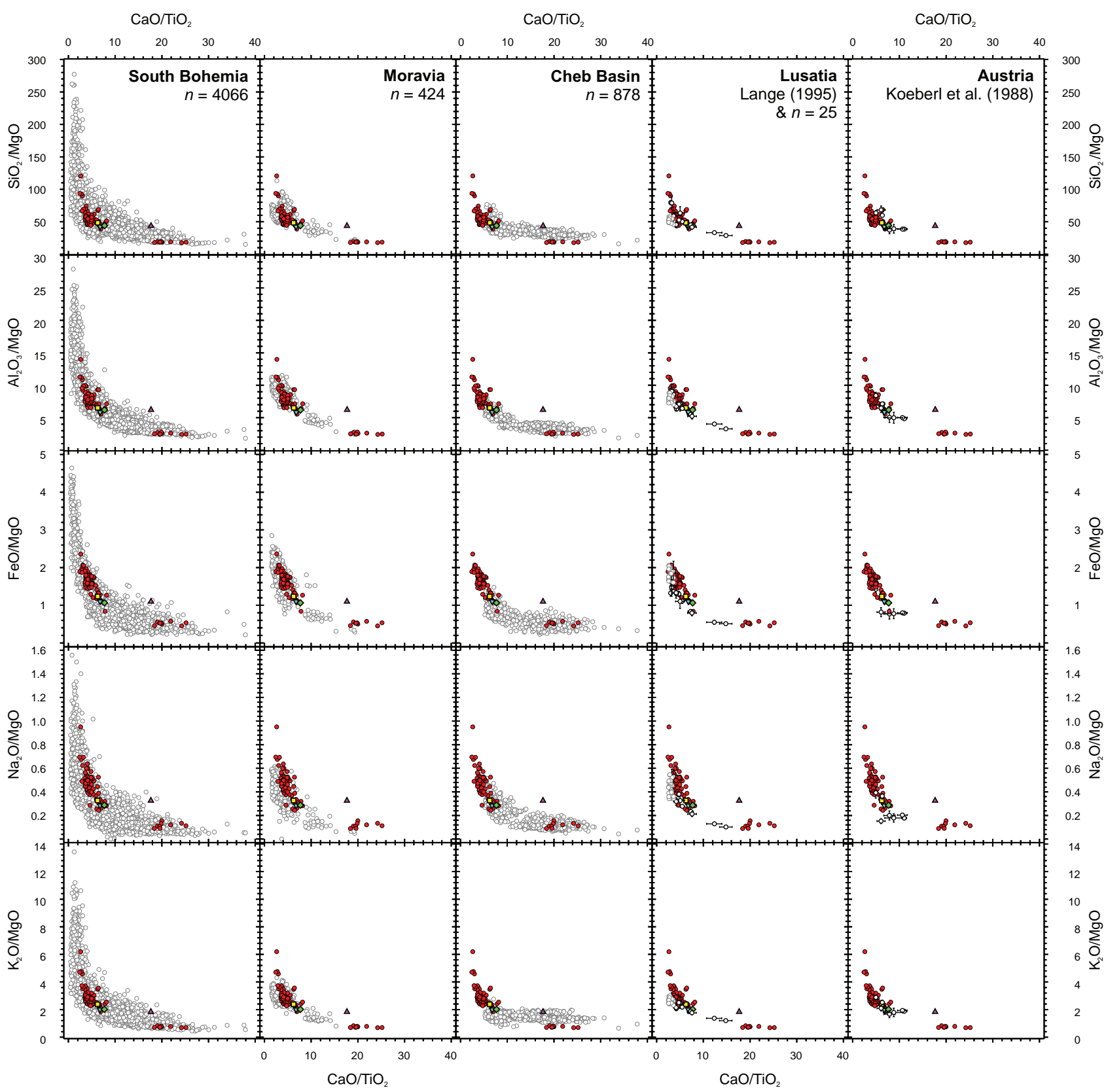

Fig. 10 Oxide ratio plots for the NS-4 moldavite compared to the trends defined by CET from other sub-strewn fields. Point analyses of the Polish moldavites form two clearly separated clusters.

several ratios depart substantially from values normally reported for $\mathrm{UCC}$, including $\mathrm{Rb} / \mathrm{Cs}$ with average of 9.1 in the moldavite vs. 17 for UCC, Rb/Sr 1.13 vs. 0.26 or $\mathrm{Sr} /$ Nd 5.01 vs. 11.85. Figure 12 compares UCC-normalized contents of selected elements for studied moldavite and those from traditional sub-strewn fields. Similar to Fig. 11, there is a fairly good agreement among the data from various regions. The spiderplots demonstrate considerable enrichments in $\mathrm{Cs}, \mathrm{Rb}$ and $\mathrm{Li}$ and substantial depletion in $\mathrm{W}, \mathrm{Pb}, \mathrm{Sr}, \mathrm{P}, \mathrm{Sn}, \mathrm{Sc}, \mathrm{V}, \mathrm{Zn}, \mathrm{Cu}, \mathrm{Co}, \mathrm{Cr}$ and Ni compared to UCC.
A correlation of major-, minor- and trace-element compositions along a line profile crossing the area with high-Ca-Mg schlieren is shown in Fig. 13. Table 2 summarizes average compositions calculated for selected regions along this profile. Some elements display substantial compositional variability (e.g., $\mathrm{B}, \mathrm{Mg}, \mathrm{P}, \mathrm{K}, \mathrm{Ca}$, $\mathrm{Mn}, \mathrm{Zn}, \mathrm{Ga}$ and $\mathrm{Pb}$ ) whereas contents of others remain almost invariant (e.g., Li, Be, Sc, Cu, HREE and Ta). Among the elements showing large compositional variations the strong mutual positive correlations exist within the two groups of elements: $\mathrm{Mg}, \mathrm{Ca}, \mathrm{Mn}$ and $\mathrm{Si}, \mathrm{K}, \mathrm{B}, \mathrm{P}$, 
Tab. 2 Minor- and trace-element compositions (in ppm) of the sample NS-4

\begin{tabular}{|c|c|c|c|c|c|c|c|c|c|c|c|}
\hline \multirow[b]{3}{*}{$\mathrm{n}$} & \multicolumn{3}{|c|}{ Homogeneous } & \multicolumn{2}{|c|}{$61-89 \mu \mathrm{m}$} & \multicolumn{2}{|c|}{$335-357 \mu \mathrm{m}$} & \multicolumn{2}{|c|}{$543-559 \mu \mathrm{m}$} & \multicolumn{2}{|c|}{$882-942 \mu \mathrm{m}$} \\
\hline & range & mean & $\mathrm{SD}$ & mean & SD & mean & SD & mean & SD & mean & SD \\
\hline & \multicolumn{3}{|c|}{7} & \multicolumn{2}{|c|}{6} & \multicolumn{2}{|c|}{5} & \multicolumn{2}{|c|}{4} & \multicolumn{2}{|c|}{12} \\
\hline $\mathrm{Li}$ & $43-46$ & 44 & 1 & 52 & 1 & 52 & 2 & 44 & 1 & 47 & 2 \\
\hline $\mathrm{Be}$ & $2.2-2.6$ & 2.4 & 0.1 & 2.2 & 0.2 & 2.4 & 0.2 & 2.0 & 0.3 & 2.6 & 0.3 \\
\hline B & $36-43$ & 38 & 2 & 14 & 1 & 13 & 1 & 39 & 2 & 33 & 2 \\
\hline $\mathrm{P}$ & $220-284$ & 238 & 20 & 127 & 12 & 146 & 19 & 249 & 10 & 201 & 11 \\
\hline Sc & $6.2-6.9$ & 6.5 & 0.2 & 5.0 & 0.3 & 5.0 & 0.1 & 4.7 & 0.2 & 6.4 & 0.6 \\
\hline $\mathrm{Ti}$ & $2468-2848$ & 2641 & 128 & 1986 & 54 & 2182 & 55 & 2009 & 94 & 2801 & 215 \\
\hline V & $38-43$ & 40 & 2 & 25 & 1 & 27 & 1 & 36 & 2 & 44 & 4 \\
\hline $\mathrm{Cr}$ & $31-36$ & 33 & 2 & 25 & 1 & 21 & 1 & 25 & 1 & 35 & 3 \\
\hline Mn & $300-379$ & 351 & 32 & 951 & 77 & 701 & 163 & 178 & 2 & 365 & 33 \\
\hline Co & $6.9-8.2$ & 7.6 & 0.5 & 5.3 & 0.2 & 4.3 & 0.5 & 5.3 & 0.3 & 7.1 & 0.6 \\
\hline $\mathrm{Ni}$ & $22-26$ & 24 & 2 & 11 & 1 & 7 & 2 & 16 & 2 & 24 & 4 \\
\hline $\mathrm{Cu}$ & $1.20-1.30$ & 1.24 & 0.04 & 0.74 & 0.41 & 0.45 & 0.08 & 0.39 & 0.07 & 0.87 & 0.16 \\
\hline $\mathrm{Zn}$ & $22-36$ & 30 & 4 & 9 & 1 & 10 & 1 & 32 & 2 & 22 & 2 \\
\hline $\mathrm{Ga}$ & $10.6-12.3$ & 11.2 & 0.5 & 2.9 & 0.3 & 3.6 & 0.4 & 7.6 & 0.3 & 8.3 & 0.8 \\
\hline $\mathrm{Ge}$ & $0.45-0.70$ & 0.53 & 0.09 & 0.18 & 0.05 & 0.22 & 0.07 & 0.50 & 0.05 & 0.31 & 0.07 \\
\hline As & $0.95-1.16$ & 1.01 & 0.07 & 0.40 & 0.07 & 0.35 & 0.08 & 0.72 & 0.05 & 0.70 & 0.10 \\
\hline $\mathrm{Rb}$ & $147-161$ & 153 & 4 & 113 & 5 & 105 & 6 & 148 & 6 & 142 & 7 \\
\hline $\mathrm{Sr}$ & $121-134$ & 126 & 4 & 140 & 5 & 149 & 13 & 108 & 5 & 123 & 7 \\
\hline Y & $19-21$ & 20 & 1 & 17 & 1 & 18 & 1 & 16 & 1 & 18 & 1 \\
\hline $\mathrm{Zr}$ & $221-250$ & 233 & 10 & 220 & 7 & 227 & 18 & 196 & 8 & 217 & 14 \\
\hline $\mathrm{Nb}$ & $8.7-9.8$ & 9.3 & 0.4 & 7.7 & 0.3 & 7.8 & 0.6 & 8.6 & 0.5 & 9.8 & 0.5 \\
\hline Mo & $0.068-0.094$ & 0.078 & 0.008 & n.d. & & n.d. & & n.d. & & n.d. & \\
\hline Ag & $0.044-0.052$ & 0.046 & 0.003 & n.d. & & n.d. & & n.d. & & n.d. & \\
\hline Sn & $0.71-1.17$ & 0.90 & 0.14 & 0.29 & 0.02 & 0.29 & 0.08 & 1.11 & 0.12 & 0.63 & 0.06 \\
\hline $\mathrm{Sb}$ & $0.12-0.15$ & 0.13 & 0.01 & 0.07 & 0.01 & 0.06 & 0.01 & 0.13 & 0.01 & 0.12 & 0.03 \\
\hline Cs & $15.2-17.3$ & 16.3 & 0.7 & 13.8 & 0.3 & 12.1 & 1.2 & 14.4 & 0.6 & 15.6 & 0.9 \\
\hline $\mathrm{Ba}$ & $763-814$ & 796 & 18 & 803 & 25 & 838 & 75 & 725 & 36 & 744 & 47 \\
\hline $\mathrm{La}$ & $28.9-31.6$ & 30.0 & 0.9 & 28.1 & 0.9 & 29.0 & 2.2 & 24.5 & 1.1 & 27.8 & 1.9 \\
\hline $\mathrm{Ce}$ & $60-64$ & 62 & 1 & 62 & 2 & 68 & 3 & 52 & 2 & 61 & 4 \\
\hline $\operatorname{Pr}$ & $6.6-7.1$ & 6.9 & 0.2 & 6.6 & 0.3 & 6.9 & 0.5 & 5.6 & 0.2 & 6.6 & 0.4 \\
\hline $\mathrm{Nd}$ & $25.5-28.0$ & 26.7 & 0.8 & 25.6 & 1.3 & 26.5 & 2.4 & 22.0 & 1.5 & 25.1 & 1.7 \\
\hline Sm & $4.9-5.5$ & 5.2 & 0.2 & 4.8 & 0.3 & 5.1 & 0.4 & 4.4 & 0.4 & 4.8 & 0.3 \\
\hline $\mathrm{Eu}$ & $0.96-1.04$ & 0.99 & 0.03 & 0.91 & 0.05 & 0.93 & 0.08 & 0.84 & 0.02 & 0.95 & 0.04 \\
\hline Gd & $3.9-4.4$ & 4.1 & 0.2 & 3.8 & 0.3 & 3.8 & 0.3 & 3.3 & 0.2 & 3.7 & 0.3 \\
\hline $\mathrm{Tb}$ & $0.57-0.66$ & 0.61 & 0.03 & 0.56 & 0.04 & 0.54 & 0.05 & 0.47 & 0.03 & 0.53 & 0.03 \\
\hline Dy & $3.4-3.9$ & 3.6 & 0.2 & 3.4 & 0.2 & 3.4 & 0.4 & 2.9 & 0.2 & 3.2 & 0.3 \\
\hline Но & $0.66-0.76$ & 0.71 & 0.03 & 0.63 & 0.03 & 0.66 & 0.05 & 0.57 & 0.04 & 0.65 & 0.04 \\
\hline $\mathrm{Er}$ & $1.88-2.11$ & 1.99 & 0.09 & 1.86 & 0.07 & 1.83 & 0.10 & 1.63 & 0.11 & 1.84 & 0.17 \\
\hline $\mathrm{Tm}$ & $0.277-0.304$ & 0.288 & 0.009 & 0.277 & 0.030 & 0.273 & 0.034 & 0.237 & 0.019 & 0.272 & 0.025 \\
\hline $\mathrm{Yb}$ & $1.83-2.07$ & 1.95 & 0.09 & 1.78 & 0.07 & 1.87 & 0.27 & 1.59 & 0.12 & 1.76 & 0.17 \\
\hline $\mathrm{Lu}$ & $0.28-0.31$ & 0.29 & 0.01 & 0.24 & 0.01 & 0.25 & 0.03 & 0.20 & 0.04 & 0.24 & 0.04 \\
\hline $\mathrm{Hf}$ & $6.1-7.0$ & 6.5 & 0.3 & 5.7 & 0.2 & 5.9 & 0.4 & 5.2 & 0.5 & 5.7 & 0.4 \\
\hline $\mathrm{Ta}$ & $0.69-0.78$ & 0.74 & 0.03 & 0.63 & 0.03 & 0.66 & 0.08 & 0.69 & 0.03 & 0.78 & 0.06 \\
\hline W & $0.86-0.91$ & 0.88 & 0.02 & 0.34 & 0.04 & 0.40 & 0.05 & 0.84 & 0.12 & 0.89 & 0.08 \\
\hline $\mathrm{Pb}$ & $6.8-10.0$ & 8.1 & 1.0 & 2.3 & 0.1 & 2.3 & 0.2 & 9.4 & 0.3 & 5.5 & 0.3 \\
\hline $\mathrm{Bi}$ & $0.012-0.026$ & 0.017 & 0.004 & 0.006 & 0.001 & 0.006 & 0.002 & 0.031 & 0.002 & 0.011 & 0.002 \\
\hline Th & $11.5-13.0$ & 12.3 & 0.6 & 12.7 & 0.5 & 12.8 & 1.5 & 10.0 & 0.6 & 11.3 & 0.7 \\
\hline U & $2.58-2.76$ & 2.66 & 0.05 & 2.44 & 0.08 & 2.28 & 0.22 & 2.51 & 0.14 & 2.61 & 0.19 \\
\hline
\end{tabular}

The range, mean, and standard deviation (SD) for analyses taken from a more homogeneous part of the sample are given, supplemented with means and corresponding standard deviations for analyses of glass along a profile through region of the sample with high-Ca-Mg schlieren. The numbers of analyses involved in the calculation of these variables (n) are also shown. 


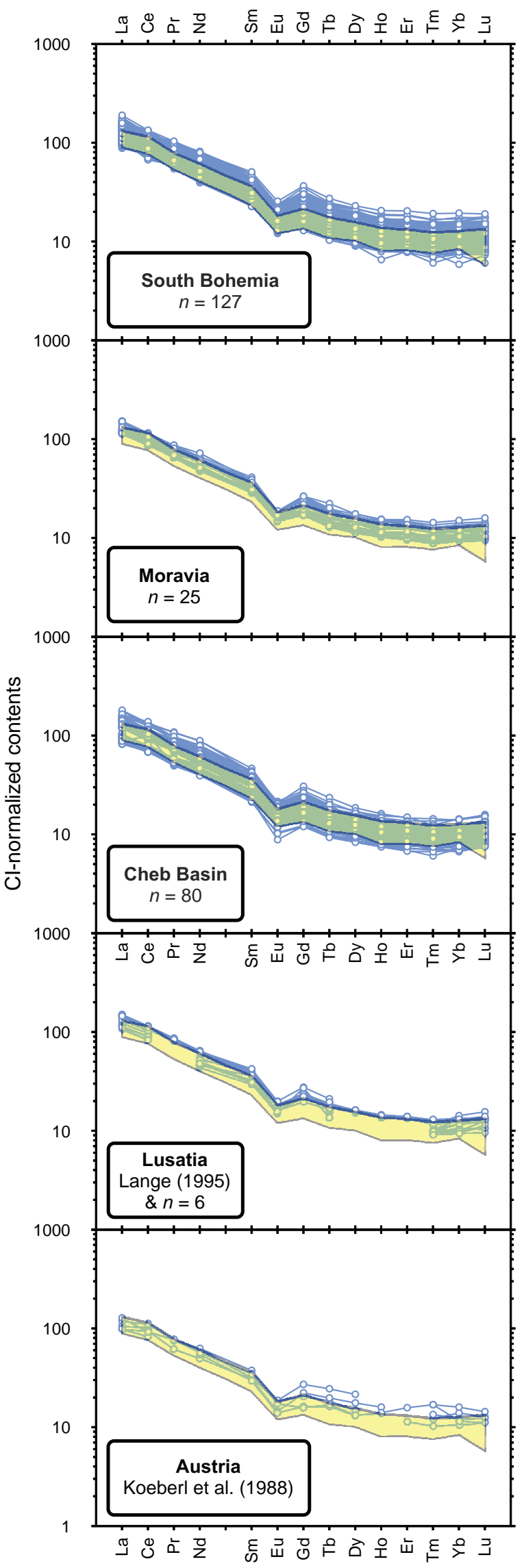

$\mathrm{Zn}, \mathrm{Ga}$ and $\mathrm{Pb}$. On the contrary, the correlations between elements belonging to different groups are negative.

The combined major- and trace-element data from EPMA and LA-ICP-MS in lechatelierite represent the first compositional information for a single lechatelierite inclusion $(\sim 300 \times 200 \mu \mathrm{m})$ in a moldavite. This pure silica glass $\left(\mathrm{SiO}_{2}\right.$ contents measured by EPMA vary between 99.4 and 100.9 wt. \%) contains very low abundances of detected elements (in ppm; determined by LA-ICP-MS): $\mathrm{Na}$ (62), Mg (48), Al (336), P (11), K (485), Ca (32), Ti (45), V (0.27), Cr (0.21), Mn (2.4), Fe (142), Co (0.33), $\mathrm{Ni}(0.36), \mathrm{Cu}(0.37)$ and $\mathrm{Ga}(0.26)$. Compared to the moldavite glass, lechatelierite is enriched in $\mathrm{Cu}$, whilst $\mathrm{Ca}$ or $\mathrm{Mg}$ are depleted. On the other hand, $\mathrm{Na}_{2} \mathrm{O} / \mathrm{K}_{2} \mathrm{O}$ ratio is the same within experimental error.

\section{Discussion}

\subsection{Size, morphology and chemical composition}

Brachaniec et al. $(2014,2015)$ reported weights for all 16 to date known Polish moldavites. They are rather small with the largest piece weighing $0.53 \mathrm{~g}$ (from locality Gozdnica) whereas the smallest one is only $0.003 \mathrm{~g}$ (North Stanisław). These authors concluded that the small masses of individual samples and the trend of eastward decreasing weight indicate re-deposition of moldavites found in Poland from the Lusatian sub-strewn field. The observations were explained by a fluvial transport, expected to be associated with gradual fragmentation of originally larger moldavites and progressive loss of their mass. However, only little is known about the distribution of moldavite fragments of such a weight at classical localities in Bohemia and Moravia since neither private collectors nor commercial enterprises are interested in small-sized fragments. Therefore, these less-than-gram pieces often escaped undetected. Consequently, their weight is not recorded resulting in shifting the mass distribution curves (e.g., Bouška and Konta 1986) towards higher mean weights. Also, it should be taken into account that only pieces exceeding a few tenths of a gram are physically recoverable during standard handling of moldavite-bearing sediments. There are only a few statistically well constrained reports focused on detailed study of moldavite weights in certain localities.

Fig. 11 Chondrite-normalized rare earth element patterns for the sample NS-4 (yellow field) compared to data for moldavites from other sub-strewn fields (light blue circles). Data sources: Koeberl et al. (1988), Lange (1995), Di Vincenzo and Skála (2009), Skála et al. (2009), Magna et al. (2011) and unpublished authors' analyses. Normalizing data from Palme and O’Neill (2014). 


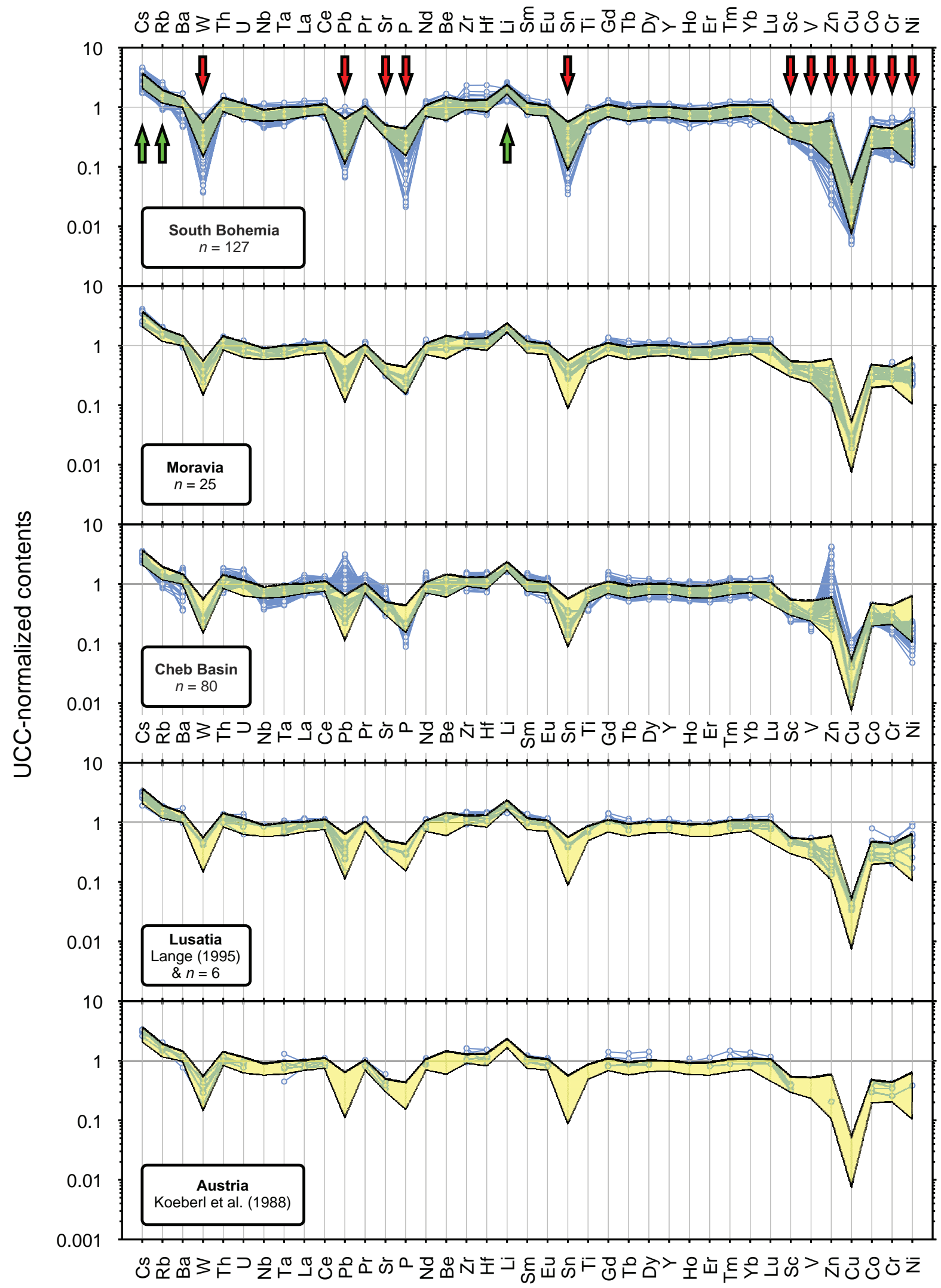

Fig. 12 Upper continental crust-normalized contents of minor and trace elements in the NS-4 moldavite (yellow field) compared to data for moldavites from the classical sub-strewn fields (light blue circles). Red arrows indicate elements substantially depleted in the sample compared to UCC contents, green arrows denote enriched elements. Data for comparison are from the same sources as those in Fig. 6. Normalizing data from Rudnick and Gao (2014). 


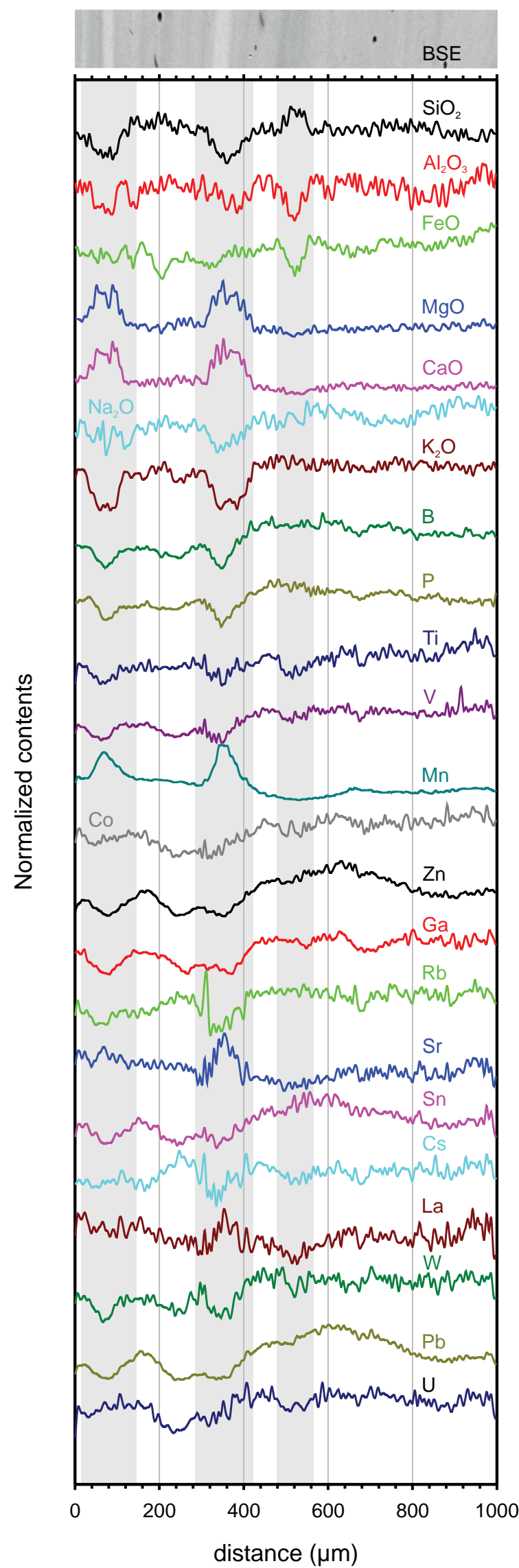

Ševčík (1990) reported results of a detailed exploration study at the Besednice locality based on a total of 77 cubic meters of sediments recovered from several test trenches. They calculated that 1 cubic meter of sediments there is containing less than $6.5 \mathrm{~g}$ of moldavites on average; however, the contents vary locally from 2 to $26 \mathrm{~g} / \mathrm{m}^{3}$ based on evaluation of several separate $1 \mathrm{~m}^{3}$ samples. The authors further claimed that about $90 \%$ of exploited moldavites weigh less than $3 \mathrm{~g}$ with most of them actually being tiny scaly-shaped fragments of less than $0.2 \mathrm{~mm}$ in thickness and $1 \mathrm{~g}$ in weight. According to Vamberková and Ševčík (1990) a weight distribution curve of a set of 908 pieces from a Bor sandpit near Suchdol nad Lužnicí displayed a maximum in the category $0-1 \mathrm{~g}(\sim 35 \%)$. Among 434 pieces from the sandpit in Jakule (near Nové Hrady), about $10 \%$ of moldavites fell in this category with a sharp maximum in the category 1-2 g ( $60 \%)$. Clearly, also irregularly shaped fragments of moldavites with weight less than $1 \mathrm{~g}$ occur at the classical localities; locally they may even prevail which is consistent with occurrences in Poland.

The shape of moldavites found in Poland is variable; in general they are angular irregular splinters and fragments, only few of them display some rounding. The sculpturing is also not uniform, several pieces display some macroscopic sculpturing whereas others are devoid of any such phenomena. Studied piece shows both macroscopic groove-like (Figs 3a-c) as well as microscopic flat-bottomed-pit-shaped sculpturing (Fig. 3d). It should be noted, however, that no samples with the sculpturing reported by Lange (1995) for fluvially transported moldavites from Lusatia were found.

In general, size and sculpturing are closely related to the mechanical properties of moldavites. Numerous authors noted the brittle character of moldavite glass, which displays substantial strain due to its thermal history and, consequently, constrains the length of transport (e.g., Bouška and Konta 1986; Trnka and Houzar 2002). Finds of moldavites near Prague (Žebera 1972) and in Germany (Lange 1995, 1996) raised questions about the durability of these glasses during fluvial transport and a possibility of re-deposition over few tens or even hundreds km. Studies of Bouška et al. (1968), Cífka et al. (1971), and Žák (2009) showed that the effective transport of tektites in water streams is limited to less than $10 \mathrm{~km}$. Similar conclusions were drawn by Lange (1996) and Bouška and Lange (1999) based on paleogeographic constraints of Lusatian area. It is apparent that Polish moldavites could have hardly resisted re-deposition from Lusatian

Fig. 13 Variability of a chemical composition along a line profile crossing the sample region with two chemically unusual high- $\mathrm{Ca}-\mathrm{Mg}$ schlieren (bright in the BSE panel at the top). Gray bars indicate the regions most chemically differing from the average composition and correlate with schlieren in the BSE image. 
sub-strewn field for over at least $50 \mathrm{~km}$ in case of Gozdnica locality or $>160 \mathrm{~km}$ in case of Rusko and Mielęcin.

Data on major-element chemistry reported by Brachaniec et al. $(2014,2015)$ overlap with those presented in this paper except for the moldavite from the Gozdnica sandpit (Figs 6-10). It should be noted, however, that there may be a yet unrecognized bias in the data by Brachaniec et al. (2015) considering the reported totals for two moldavites of 97.2 and 96.9 wt. \%, respectively.

The majority of analyses presented here matches common compositions of moldavites from other sub-strewn fields. The high-Ca-Mg schlieren, however, are a rather unique group at the edge or even outside the compositional fields defined by $\sim 5000$ electron-microprobe analyses of moldavites from other parts of the CET strewn field. Such a composition is duplicated by only several analyses of South Bohemian moldavites.

The general match of REE patterns as well as UCCnormalized spiderplots (Figs 11 and 12) for the sample NS-4 with those for CET from classical sub-strewn fields indicate a broadly common source material for all these glasses. We found substantial enrichment or depletion of some elements compared to UCC (Fig. 12), discussed elsewhere (e.g., von Engelhardt et al. 1987, 2005; Žák et al. 2016). Žák et al. (2016) suggested that the chemical differences between potential source sediments and moldavites reflect a complex multistage origin of CET.

The first ever micron-scale spatially resolved chemical variations in moldavite glass are reported in this study (Fig. 13) though previously similar techniques have been applied to, e.g., spherule-rich Cretaceous-Paleogene event bed in sediments of western Atlantic (Berndt et al. 2011) or glass spherules for Chicxulub distal ejecta in Mexico and Haiti (Belza et al. 2015). A simultaneous increase in $\mathrm{Ca}, \mathrm{Mg}, \mathrm{Mn}$ and partly $\mathrm{Sr}$ indicates that carbonate of dolomitic composition contributed to the chemistry of BSE-bright schlieren. Silicon, Na, K, B and $\mathrm{P}$ show tight mutual positive correlations pointing to a common source, probably alkali feldspars-rich, albeit quartz is the major source of moldavite melt, considering overall high silica content.

A limited number of moldavite specimens found so far in Poland and the lack of systematic studies of distribution of small-sized moldavites in CET classical sub-strewn fields makes any interpretation of weights and mass distribution trends highly speculative. Nevertheless, it appears that overall small weight of Polish moldavites follows the common trend observed in many south Bohemian sandpits (Vamberková and Ševčík 1990). Extremely small size of CET from localities in Poland, their mostly angular shape, multistage sculpturing including both remains of older deeper and superimposed shallow young phenomena, and overall brittle character of tektite glass clearly preclude a possibility of significant transport. In addition, the chemical composition does not allow unambiguously linking the Polish sub-strewn field to any other existing CET sub-strewn fields.

\subsection{Stratigraphy and paleogeography of the moldavite-bearing localities}

Stratigraphy and stratigraphic correlations of moldavitebearing sediments are commonly not well constrained, mostly due to the lack of dated fossils. Figure 14 shows a rough estimate of stratigraphic correlations across individual CET sub-strewn fields.

According to Brachaniec et al. (2014, 2015), the sands and gravels hosting moldavites in Poland stratigraphically correspond to the Gozdnica Fm. Mai and Wähnert (2000) and Szynkiewicz (2011) dated this formation to the late Miocene (Pannonian to Pontian) although others (e.g., Piwocki and Ziembińska-Tworzydło, 1997; Kramarska et al. 2015) did not exclude, at least partly, a Pliocene age.

Bouška (1972, 1988), Bouška and Konta (1986), Bouška and Lange (1999) and Ševčík et al. (2007) summarized the stratigraphy of moldavite occurrences in the South Bohemian sub-strewn field. They defined four groups: (1) The oldest sediments, so-called 'strewn field sediments', are called Vrábče Member and are assumed to represent a lateral equivalent of the basal part of the Domanín Fm. dated to the middle Miocene. Their character indicates diluvial origin of these sediments. (2) Fluvio-lacustrine sediments of Romanian (and maybe also Pleistocene) age are called 'Formation of moldavitebearing sandy gravels' by Bouška (1988) and Bouška and Lange (1999) whereas Ševčík et al. (2007) use terms Koroseky Sandy Gravel and Kamenný Újezd Gravel. It should be noted, however, that the Koroseky Sandy Gravel unit is considered a fluvial, fluvio-lacustrine and deltaic facies of the Vrábče Member by others (e.g., Žebera 1967; Trnka and Houzar 2002). (3) Moldavites of the South Bohemian sub-strewn field are present also in slope loams and scree (detritus), which belong to the Quaternary. (4) The youngest sediments are alluvial and late Quaternary deposits along the present-day streams.

Based on paleontological finds, Ševčík et al. (2007) revised the stratigraphic position of the oldest moldavitebearing sediments and paralleled them with the middle Badenian mammalian zone MN 6, which falls into the early-middle Miocene Climatic Optimum that preceded the late Badenian/Sarmatian cooling phase (13.6 Ma; Ševč́k et al. 2007).

The stratigraphy of Moravian localities is also controversial (Bouška and Lange 1999; Trnka and Houzar 1991, 2002). There is a general consensus on the age of the so-called 'strewn field sediments'. These colluvialfluvial sand-dominated sediments with gravel admixture only occur near Slavice and Třebíč. They are assumed to 

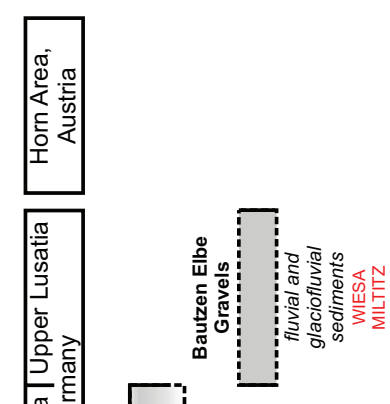

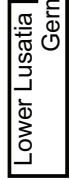

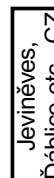

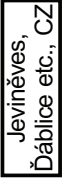

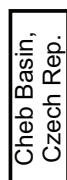
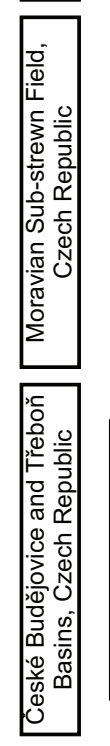

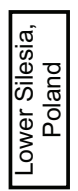

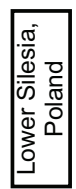

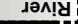

(1)

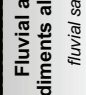
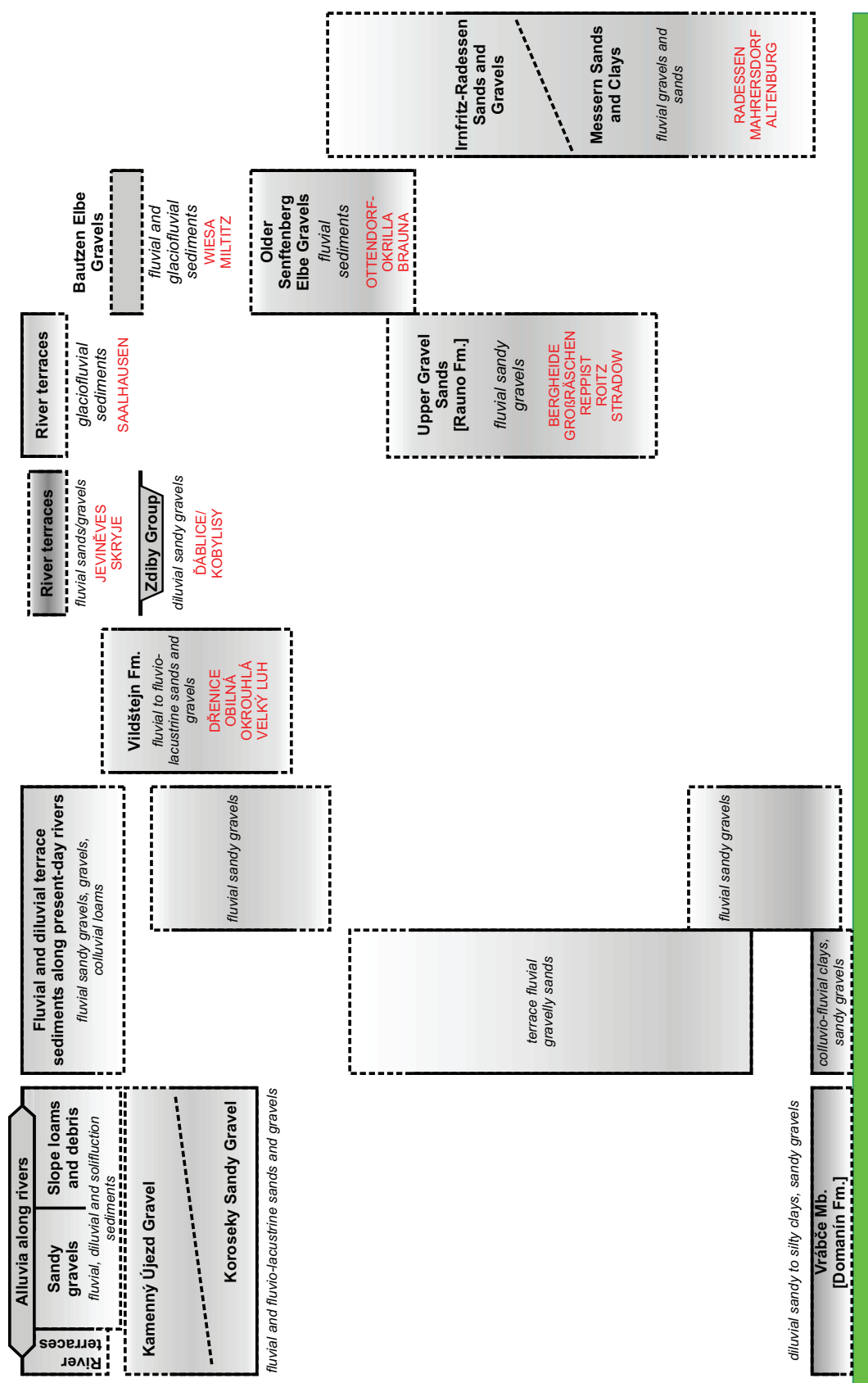
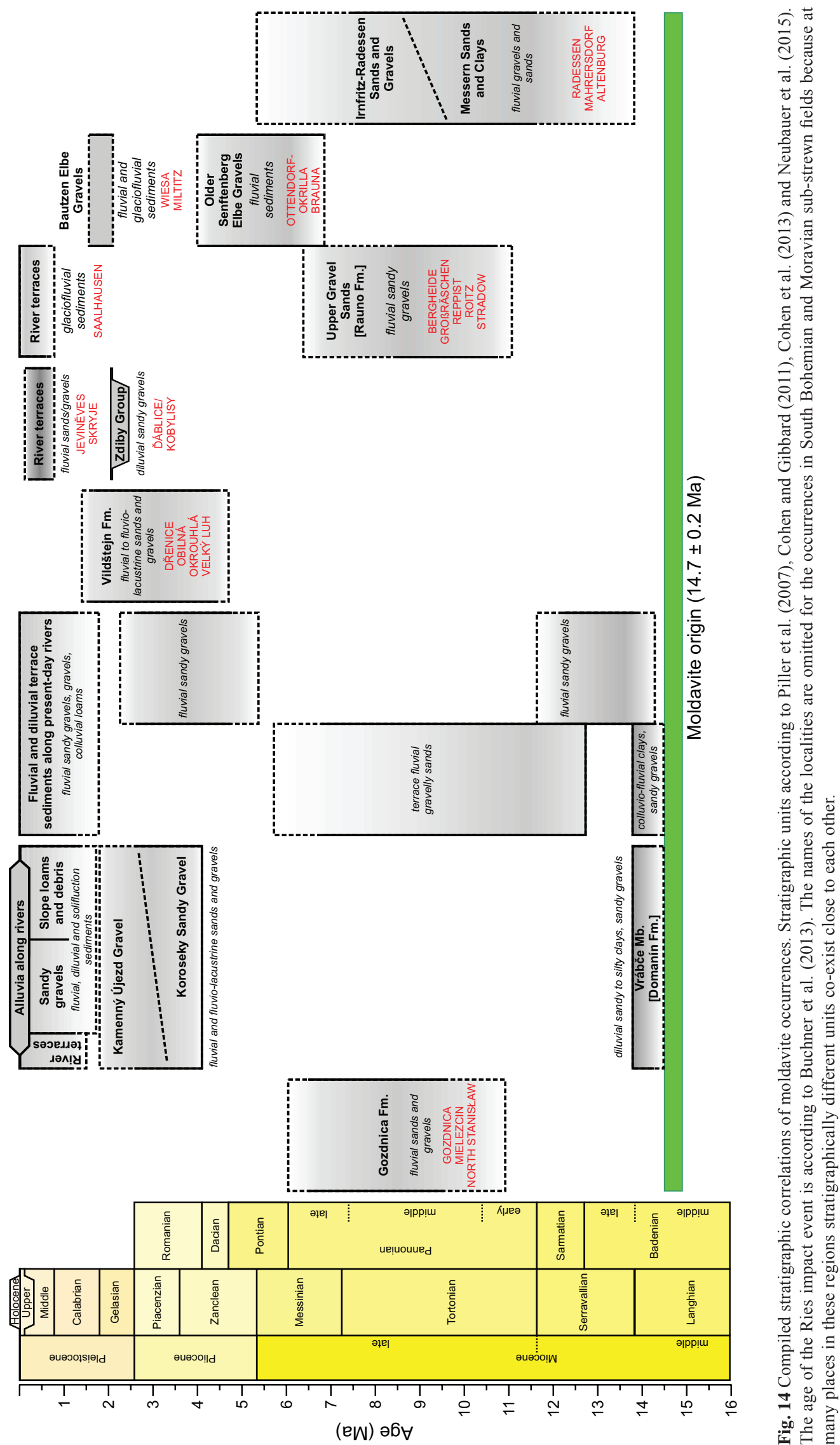
be coeval with the same type of the moldavite-bearing localities in South Bohemia, i.e., Badenian in age. Younger, mostly fluvial sandy gravels or gravelly sands are assumed to be Pliocene (Bouška and Konta 1986; Bouška and Lange 1999). However, Trnka (1990) and Trnka and Houzar $(1991,2002)$ suggested a much older age (Badenian to Sarmatian or Upper Badenian to Pannonian, respectively).

The youngest moldavite-bearing sediments in Moravia are Pleistocene gravels of river terraces, colluvial loams, and fluvial and/or diluvial sediments along recent rivers. Stratigraphically rather well-constrained are fluvial to fluvio-lacustrine sands and gravels of the Vildštejn Fm. hosting moldavites in the Cheb Basin that were dated by Bucha et al. (1990) and Špičáková et al. (2000) to the late Pliocene to early Pleistocene. Scattered finds on the territory of the Czech Republic are late Pliocene in case of Dáblice/Kobylisy sandpit and the middle Pleistocene for Jeviněves sandpit and a locality near Skryje on the Berounka River terraces (Žák et al. 1999; Tyráček 2001; Tyráček et al. 2004; Ložek and Žák 2011).

The oldest moldavite-bearing sediments in Lusatia correspond to the upper part of the Rauno Fm. (Lange 1995, 1996; Bouška and Lange 1999; Lange et al. 2009) which is assumed to be Upper Miocene in age, i.e., only slightly younger than the so-called Schipkau flora (Mai and Wähnert 2000). In Upper Lusatia two other units are hosting moldavites: Older Senftenberg Elbe Gravels and Bautzen Elbe Gravels. The former is of Pretegelen (and maybe partly uppermost Miocene) age whereas latter belongs stratigraphically to the Tegelen Complex (Lange et al. 2009). The youngest fluvial sediments with occurrences of CET are of middle to late Pleistocene age.

Austrian moldavites are rare and their stratigraphic position is poorly determined. Koeberl et al. (1988) assumed that they are contained in fluvial Irnfritz-Radessen Sands and Gravels or Messern Sands and Clays which they expect to be of Miocene age. However, Bouška and Lange (1999) did not exclude significantly younger (Pliocene-Pleistocene) age.

Sediments hosting the moldavites in Poland are much younger than Badenian sediments in Southern Bohemian or Moravian sub-strewn fields. Collectively, moldavitebearing sediments in Poland appear to be coeval with those of the Rauno Fm. in the Lower Lusatian, and the late Miocene sands and gravels in Austria.

The preservation of moldavites was possible only due to rapid burial shortly after their deposition in the middle Miocene (e.g., Trnka and Houzar 2002). This implies the existence of suitable streams and water reservoirs. Paleogeographic reconstruction of the area where moldavites may have been deposited at the time of the Ries impact event [see numerical models by Stöffler et al. (2002) or Artemieva et al. (2002)] indicates the presence of several suitable discrete sedimentation basins (cf. Fig. 6 b in Kuhlemann 2007, Fig. 1 in Lange and Suhr 2009). In addition to classical CET localities, the lacustrine and fluvial sedimentation took place in several parts of central and central-western Bohemia, and relatively large regions in Lusatia (Germany) and Lower Silesia (Poland). Consequently, it cannot be ruled out that part of moldavites was deposited also in these areas.

In the late Miocene and at the beginning of the Pliocene when the Gozdnica Fm. was deposited the areal extent of sedimentation basins suitable for accumulation of moldavites changed significantly (e.g., Suhr 2003; Badura and Przybylski 2004; Lange et al. 2009). In some parts of Lower Silesia in Poland where CET had been found, Badura and Przybylski (2004) identified numerous fluvial deposits of river courses heading to the North. According to this paleogeographic reconstruction, the locality near Gozdnica corresponds to pre-Nysa-Łuziicka River whereas Rusko and Mielęcin localities are located in sediments of pre-Bystrzyca River. Importantly, neither in the late Miocene nor in the Pliocene was a river heading from Lusatia to Lower Silesia that might have potentially transported moldavites.

Combined paleogeographic and stratigraphic constraints and mechanical properties of moldavites leads to the conclusion that the specimens found in sandpits near Gozdnica, Mielęcin, and Rusko were originally deposited in basins in the piedmont along the northern and north-eastern slopes of Sudetic Mountains. Later, during late Miocene or early Pliocene, these sediments were reworked and moldavites were transported over relatively short distances by streams heading to the North.

\section{Conclusions}

The moldavites found in sandpits close to Strzegom represent the Central European tektites most distant $(\sim 475 \mathrm{~km})$ from the source crater, the Ries impact structure in Bavaria. Another locality in Poland where moldavites were recovered, the Gozdnica sandpit, is located near the Polish-Germany border, about $430 \mathrm{~km}$ from the Ries.

The CET from Poland are fragments of variable shapes and very small weights $(0.003-0.5 \mathrm{~g})$. The number of known specimens is low preventing any comparison with localities where statistically evaluated weight distributions are available. This, in turn, makes any inferences on the length of transport highly speculative. The shapes of Polish moldavites range from angular irregular splinters to irregular fragments but no pebble-like moldavite indicating a longer fluvial transport was found. Sculpturing is rather variable, clearly multistage, indicating repeated periods of short transport, deposition and etching. 
The studied sample NS-4 from North Stanisław sandpit displays fluidal fabric on both macroscopic and the $\mu \mathrm{m}$-scale. The surface shows multiple sub-parallel grooves up to few hundreds $\mu \mathrm{m}$ wide and on a more detailed scale there are fine mutually sub-parallel ridges following the direction of grooves. There are multiple chemically different sub-parallel schlieren, with some of them up to $50 \mu \mathrm{m}$ wide. The overall fluidal fabric is locally distorted and schlieren become interwoven. Lechatelierite inclusions are common, some of them up to half a millimetre long.

The major-element chemistry of the NS-4 moldavite is highly variable. Some of the schlieren display a composition untypical of c. 5000 electron-microprobe analyses from other CET sub-strewn fields. In particular, they are extremely enriched in $\mathrm{Ca}$ and $\mathrm{Mg}$; such compositions have only been observed for the CET from the South Bohemian sub-strewn field. On the other hand, the chemical composition of the volumetrically dominant part of the studied piece follows general compositional trends observed for moldavites from other classical sub-strewn fields. The minor- and trace-element contents are compatible with the origin from surficial crustal materials undergoing high-temperature reprocessing causing strong depletion of some volatile (e.g., $\mathrm{Zn}, \mathrm{Cu}, \mathrm{Pb}$ ) and transitional elements (e.g., $\mathrm{V}, \mathrm{Ni}, \mathrm{Cr}$ ), paralleled by enrichments of some alkali elements (e.g., Li, $\mathrm{Rb}, \mathrm{Cs}$ ) relative to UCC. The most heterogeneous part of the moldavite indicates variations of both major- and trace-element composition on the micrometre scale.

Sediments hosting moldavites in Poland are assumed to be of late Miocene or early Pliocene age, coeval with those of the Upper Gravel Sands of the Rauno Fm. in Lower Lusatia and possibly also with finds in Austria. Both splintery, angular character of Polish moldavites and the generally accepted upper limit for maximum length of the effective transport of tektites, which is $c .10$ $\mathrm{km}$, imply that these finds represent pieces fluvially redeposited from a new so far unknown separate sub-strewn field located south of the place of their recent occurrence. Based on our results, the suggested re-deposition from Lusatia which would require transport for $>160 \mathrm{~km}$ is unrealistic. However, paleogeographic reconstructions of Central Europe at that time indicate the presence of palaeovalleys draining northern slopes of Sudetic Mountains and Erzgebirge to the north and such a transport appears more feasible. In any case, it is probable that both the number as well as weight of moldavites found in the region will increase with finds of new samples allowing further refinements of source and transport of moldavites in Poland.

Acknowledgements. This research was supported through the Czech Science Foundation (GAČR) project No. 13-
22351S, the Institute of Geology of the CAS Research Plan RVO67985831, and the Polish National Science Centre grant No. 2014/13/N/ST10/04921. Help with electron-microprobe data collection by Anna Langrová, Vlasta Mocová (née Böhmová), Lenka Dziková and Gabriel Molnár is appreciated. The reviews by Alex Deutsch and Stanislav Houzar helped significantly to improve the original version of the manuscript.

Electronic supplementary material. The complete analytical tables for the sample NS-4 obtained by electron microprobe and LA ICP MS are available online at the Journal web site (http://dx.doi.org/10.3190/jgeosci.214).

\section{References}

Artemieva N, Pierazzo E, Stöffler D (2002) Numerical modeling of tektite origin in oblique impacts: implication to Ries-moldavites strewn field. Bull Czech Geol Surv 77: 303-311

Badura J, Przybylski B (2004) Evolution of the Late Neogene and Eopleistocene fluvial system in the foreland of the Sudetes Mountains, SW Poland. Ann Soc Geol Polon 74: 43-61

Barth MG, McDonough WF, Rudnick RL (2000) Tracking the budget of $\mathrm{Nb}$ and $\mathrm{Ta}$ in the continental crust. Chem Geol 165: 197-213

Berndt J, Deutsch A, Schulte P, Mezger K (2011) The Chicxulub ejecta deposit at Demerara Rise (western Atlantic): dissecting the geochemical anomaly using laser ablation-mass spectrometry. Geology 39: 279-282

Belza J, Goderis S, Smit J, Vanhaecke F, Baert K, Terryn H, Claeys P (2015) High spatial resolution geochemistry and textural characteristics of 'microtektite' glass spherules in proximal Cretaceous-Paleogene sections: insights into glass alteration patterns and precursor melt lithologies. Geochim Cosmochim Acta 152: 1-38

Bland PA, de Souza Filho CR, Jull AJT, Kelley SP, Hough RM, Artemieva NA, Pierazzo E, Coniglio J, Pinotti L, Evers V, Kearsley AT (2002) A possible tektite strewn field in the Argentinian Pampa. Science 296: 1109-1111

BoušKA V (1972) Geology of the moldavite-bearing sediments and distribution of moldavites. Acta Univ Carol, Geol 1972: 1-29

BouŠKA V (1988) Geology of moldavite-bearing sediments. In: KonTA J (ed) Proceedings of the $2^{\text {nd }}$ International Conference on Natural Glasses, Prague. Charles University, Prague, pp 15-23

BoušKa V, Konta J (1986) Moldavites. Acta Univ Carol, Geol 1986: 1-85

BoušKa V, LANGE J-M (1999) Geology of the moldavitebearing sediments in Central Europe. Schr Staatl Mus Mineral Geol Dresden 10: 20-24 
BoušKa V, Faul H, Naeser CW (1968) Size, shape and color distribution of moldavites. Acta Univ Carol, Geol 4: 277-286

Bouška V, Mottl V, Rost R, Ševčík J (1995) Moldavites from the Cheb Basin. Bull Czech Geol Surv 70: 73-80

Brachaniec T, Szopa K, Karwowski Ł (2014) Discovery of the most distal Ries tektites found in Lower Silesia, southwestern Poland. Meteorit Planet Sci 49: 1-8

Brachaniec T, Szopa K, Karwowski Ł (2015) A new discovery of parautochthonous moldavites in southwestern Poland, Central Europe. Meteorit Planet Sci 50: 1697-1702

Bucha V, Horáček J, Malkovský M (1990) Palaeomagnetic stratigraphy of the Tertiary of the Cheb Basin (W Bohemia). Věstník ÚÚG 65: 267-278

Buchner E, Schwarz WH, Schmieder M, Trieloff M (2010) Establishing a 14.6 $\pm 0.2 \mathrm{Ma}$ age for the Nördlinger Ries impact (Germany) - a prime example for concordant isotopic ages from various dating materials. Meteorit Planet Sci 45: 662-674

Buchner E, Schmieder M, Schwarz WH, Trieloff M (2013) Das Alter des Meteoritenkraters Nördlinger Ries - eine Übersicht und kurze Diskussion der neueren Datierungen des Riesimpakts. Z Dtsch Ges Geowiss 164: 433-445

Cífka S, Horský J, Kos M, Prchal M, ŠKrov G, Uhlíř F (1971) A collective work by members of the young astronomer's club at the Public's Observatory in České Budějovice, Flight direction of moldavites and their overall mass. Mem Observ Czech Astron Soc of the Czech Acad Sci 14: 42-51

COHEN KM, GiBBARd P (2011) Global chronostratigraphical correlation table for the last 2.7 million years. Subcommission on Quaternary Stratigraphy (International Commission on Stratigraphy), Cambridge, England

Cohen KM, Finney SC, Gibbard PL, Fan J-X (2013, updated) The ICS International Chronostratigraphic Chart. Episodes 36: 199-204

Condie KC (1993) Chemical composition and evolution of the upper continental crust: contrasting results from surface samples and shales. Chem Geol 104: 1-37

David K, Schiano P, Allègre CJ (2000) Assessment of the $\mathrm{Zr} / \mathrm{Hf}$ fractionation in oceanic basalts and continental materials during petrogenetic processes. Earth Planet Sci Lett 178: 285-301

Deutsch A, Ostermann M, Masaitis VL (1997) Geochemistry and neodymium-strontium isotope signature of tektite-like objects from Siberia (urengoites, South-Ural glass). Meteorit Planet Sci 32: 679-686

Delano JW, Lindsley DH (1982) Chemical systematics among the moldavite tektites. Geochim Cosmochim Acta 46: 2447-2452

Di Vincenzo G, Skála R (2009) ${ }^{40} \mathrm{Ar}-{ }^{39} \mathrm{Ar}$ laser dating of tektites from the Cheb Basin (Czech Republic): evidence for coevality with moldavites and influence of the dat- ing standard on the age of the Ries impact. Geochim Cosmochim Acta 73: 493-513

Jochum KP, Weis U, Stoll B, Kuzmin D, Yang Q, Raczek I, Jacob DE, Stracke A, Birbaum K, Frick DA, Günther D, ENZWEILER J (2011) Determination of reference values for NIST SRM 610-617 glasses following ISO guidelines. Geostand Geoanal Res 35: 397-429

Jourdan F, Reimold WU, Deutsch A (2012) Dating terrestrial impact structures. Elements 8: 49-53

Kamber BS, Greig A, Collerson KD (2005) A new estimate for the composition of weathered young upper continental crust from alluvial sediments, Queensland, Australia. Geochim Cosmochim Acta 69: 1041-1058

Koeberl C (1990) The geochemistry of tektites: an overview. Tectonophysics 171: 405-422

Koeberl C (2014) The geochemistry and cosmochemistry of impacts. In: Holland HD, TureKian KK (eds) Treatise on Geochemistry (Second Edition), Volume 2: Planets, Asteroids, Comets and The Solar System. Elsevier, Oxford, pp 73-118

Koeberl C, Brandstätter F, Niedermayr G, Kurat G (1988) Moldavites from Austria. Meteoritics 23: 325-332

Kramarska R, Kasiński JR, Czapowski G, Piwocki M, SŁodkowsKa B (2015) The standard section of Neogene deposits from Eastern Pomerania at Łęczyce near Lębork (northern Poland). Biul Państw Inst Geolog 461: 193-250 (in Polish)

Kuhlemann J (2007) Paleogeographic and paleotopographic evolution of the Swiss and Eastern Alps since the Oligocene. Global Planet Change 58: 224-236

LANGE J-M (1995) Lausitzer Moldavite und ihre Fundschichten. Verlag der Gesellschaft für Geowissenschaften e.V., Berlin, pp 1-134

LANGe J-M (1996) Tektite glasses from Lusatia (Lausitz), Germany. Chem Erde 56: 498-510

LAnge J-M, Suhr P (2009) Paläogeographie und vergleichende Stratigraphie des Riesereignisses. Schriftenr Dt Ges Geowiss 63: 48-49

Lange J-M, Alexowsky W, Horna F (2009) Neogen und Quartär im Elbtal und in der Westlausitz. In: LANGE J-M, Linnemann U, RöHLing H-G (eds) GeoDresden2009. Geologie der Böhmischen Masse - Regionale und Angewandte Geowissenschaften in Mitteleuropa, 161. Jahrestagung Deutsche Gesellschaft für Geowissenschaften, 30. 09.-02. 10. 2009 in Dresden. Exkursionsführer. - Exkurs F und Veröfftl DGG 241: 151-164

LoŽEK V, ŽÁK K (2011) Tertiary and Quaternary sediments and geomorphological evolution of the Krrivoklát area. Bohemia Cent 31: 49-94 (in Czech)

Magna t, Deutsch A, Mezger K, Skála R, Seitz H-M, Mizera J, ŘAnda Z, Adolph L (2011) Lithium in tektites and impact glasses: implications for sources, histories and large impacts. Geochim Cosmochim Acta 75: 2137-2158 
Mai DH, Wähnert V (2000) On the problems of the Pliocene floras in Lusatia and Lower Silesia. Acta Palaeobot 40: $165-205$

Münker C, Pfänder JA, Weyer S, Büchl A, Kleine T, MezGer K (2003) Evolution of planetary cores and the Earth-Moon system from $\mathrm{Nb} / \mathrm{Ta}$ systematics. Science 301: 84-87

Neubauer TA, Georgopoulou E, Kroh A, Harzhauser M, Mandic O, Esu D (2015) Synopsis of European Neogene freshwater gastropod localities: updated stratigraphy and geography. Palaeontologia Electronica. 18.1.3T: 1-7

O'Keefe JA (1976) Tektites and Their Origin. Elsevier, New York, pp 1-266

Ostermann M, Deutsch A, Masaitis VL (1996) Geochemistry and Nd-Sr isotope signature of tektites (indochinites, urengoite) and impact melt glasses (zhamanshinites, irghizites). Lunar Planet Sci 27: 987-988

Palme H, O'Neill HStC (2014) Cosmochemical Estimates of Mantle Composition. In: Holland HD, Turekian KK (eds) Treatise on Geochemistry (Second Edition), Volume 3: The Mantle and Core. Elsevier, Oxford, pp 1-39

Paton C, Hellstrom J, Paul B, Woodhead J, Hergt J (2011) Iolite: freeware for the visualisation and processing of mass spectrometer data. J Anal Atom Spectr 26: 2508-2518

Piller We, Harzhauser M, Mandic O (2007) Miocene Central Paratethys stratigraphy - current status and future directions. Stratigraphy 4: 151-168

Piwocki M, Ziembińska-TworZydeo M (1997) Neogene of the Polish Lowlands - lithostratigraphy and pollen-spore zones. Geol Q 41: 21-40

Povenmire H, Burrer B, Cornec JH, Harris RS (2012) The new Central American tektite strewn field. $43^{\text {rd }}$ Lunar Planet Sci Conf, abstract \#1260

RUDNICK RL, GAO S (2014) Composition of the continental crust. In: Holland HD, Turekian KK (eds) Treatise on Geochemistry (Second Edition), Volume 4: The Crust. Elsevier, Oxford, pp 1-51

Řanda Z, Mizera J, Frána J, Kučera J (2008) Geochemical characterization of moldavites from a new locality, the Cheb Basin, Czech Republic. Meteorit Planet Sci 43: 461-467

Schultz PH, Zárate M, Hames WE, Harris RS, Bunch TE, Koeberl C, Renne P, WittKe J (2006) The record of Miocene impacts in the Argentine Pampas. Meteorit Planet Sci 41: 749-771

Schwarz WH, Lippolt HJ (2014) ${ }^{40} \mathrm{Ar}-{ }^{39} \mathrm{Ar}$ step-heating of impact glasses from the Nördlinger Ries impact craterimplications on excess argon in impact melts and tektites. Meteorit Planet Sci 49: 1023-1036

Schwarz WH, Trieloff M, Bollinger K, Gantert N, Fernandes VA, Meyer H-P, Povenmire H, Jessberger EK, Guglielmino M, Koeberl C (2016) Coeval ages of Australasian, Central American and Western Canadian tektites reveal multiple impacts $790 \mathrm{ka}$ ago. Geochim Cosmochim Acta 178: 307-319

Skála R, Strnad L, McCammon C, Čada M (2009) Moldavites from the Cheb Basin, Czech Republic. Geochim Cosmochim Acta 73: 1145-1179

Stöffler D, Artemieva NA, Pierazzo E (2002) Modeling the Ries-Steinheim impact event and the formation of the moldavite strewn field. Meteorit Planet Sci 37: 1893-1907

SuHR P (2003) The Bohemian Massif as a catchment area for the NW European Tertiary Basin. Geolines 15: 147-159

SzYNKIEWICZA (2011) The age of Neogene deposits on western part of Lower Silesia. In: ŻELAŻNIEWICZ A, WoJEWOdA J, CieżKowski W (eds) Mezozoik i Kenozoik Dolnego Sląska. WIND, Wrocław, pp 11-18 (in Polish)

ŠEVČík J (1990) The results of exploration works on Besednice locality. Sborník referátů 5. Konference o vltavínech v Českých Budějovicích 20.-21. ř́ijna 1987. Sbor Jihočes Muz (České Budějovice), přír Vědy 30 Suppl 1: 85-91 (in Czech)

ŠEVČí J, KVAČEK Z, MAI DH (2007) A new mastixioid florula from tektite-bearing deposits in South Bohemia, Czech Republic (Middle Miocene, Vrábče Member). Bull Geosci 82: 429-426

ŠPIČÁKová L, UličnÝ D, Koudelková G (2000) Tectonosedimentary evolution of the Cheb Basin (NW Bohemia, Czech Republic) between late Oligocene and Pliocene: a preliminary note. Stud Geophys Geod 44: 556-580

TRNKA M (1990) Moldavite-bearing sediments in Moravia. Sborník referátů 5. Konference o vltavínech v Českých Budějovicích 20.-21. ř́ina 1987. Sbor Jihočes Muz (České Budějovice), přír Vědy 30 Suppl 1: 92-100 (in Czech)

Trnka M, Houzar S (1991) Moravian Moldavites. Vlastivědná knihovna moravská, Svazek 76. Muzejní a vlastivědná společnost v Brně, Západomoravské muzeum v Třebíči, pp 1-115 (in Czech)

TrnKa M, Houzar S (2002) Moldavites: a review. Bull Czech Geol Surv 77: 283-302

TYRÁČEK J (2001) Upper Cenozoic fluvial history in the Bohemian Massif. Quatern Int 79: 37-53

TyráČEK J, Westaway R, Bridgland D (2004) River terraces of the Vltava and Labe (Elbe) system, Czech Republic, and their implications for the uplift history of the Bohemian Massif. Proc Geol Assoc 115: 101-124

VAMBERKOVÁ O, ŠEVČíK J (1990) The statistical evaluation of moldavite occurrences in the Bor, Hrdlořezy and Jakule localities. Sborník referátů 5. Konference o vltavínech v Českých Budějovicích 20.-21. října 1987. Sbor Jihočes Muz (České Budějovice), přír Vědy 30 Suppl 1: 106-124 (in Czech)

von Engelhardt W, Luft E, Arndt J, Schock H, WeiskirchNER W (1987) Origin of moldavites. Geochim Cosmochim Acta 51: 1425-1443 
von Engelhardt W, Berthold C, Wenzel T, Dehner T (2005) Chemistry, small-scale inhomogeneity, and formation of moldavites as condensates from sands vaporized by the Ries impact. Geochim Cosmochim Acta 69: 5611-5626

Ž́̇K K (2009) A study of gravel transport paths in a stream using metallurgical slag as a tracer: a contribution to the understanding of fluvial moldavite redistribution. Bull mineral-petrolog odd Nár Muz (Praha) 17: 79-90 (in Czech)

ŽÁK K, BouŠKA V, KADLEC J (1999) Find of a moldavite in fluvial sediments of Vltava River in sandpit near Jeviněves north of Kralupy nad Vltavou. Bull mineralpetrolog odd Nár Muz (Praha) 7: 242-243 (in Czech)
ŽÁK K, SkÁla R, ŘAnda Z, Mizera J (2012) A review of volatile compounds in tektites, and carbon content and isotopic composition of moldavite glass. Meteorit Planet Sci 47: 1010-1028

Žák K, Skála R, Řanda Z, Mizera J, Heissig K, Ackerman L, Durišová J, JonÁŠová Š, Kameník J, Magna T (2016) Chemistry of Tertiary sediments in the surroundings of the Ries impact structure and moldavite formation revisited. Geochim Cosmochim Acta 179: 287-311

ŽEBERA K (1967) Moldavite-bearing sediments between Koroseky and Holkov in South Bohemia. Věst Ústř úst geol 42: 327-337

ŽEBERA K (1972) Moldavites in catastrophic flood sediments near Prague. Geol průzk 14: 54-56 (in Czech) 